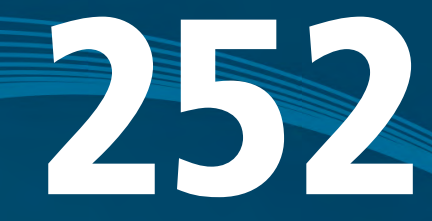

\title{
BRAZILIAN NUCLEAR-POWERED SUBMARINE: NATIONAL DEFENSE AND TECHNOLOGICAL EXTERNALITIES
}

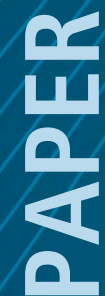

Israel de Oliveira Andrade Márcio Magno de Farias Franco e Silva Giovanni Roriz Lyra Hillebrand Luiz Gustavo Aversa Franco

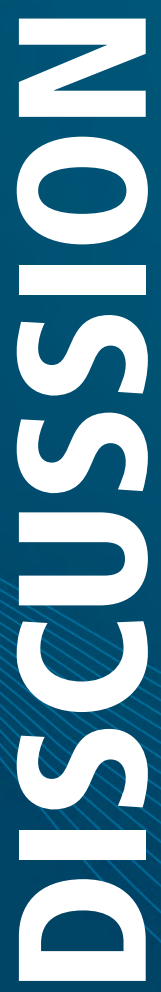





\section{DISCUSSION PAPER}

Brasilia, October 2020

\section{BRAZILIAN NUCLEAR-POWERED SUBMARINE: NATIONAL DEFENSE AND TECHNOLOGICAL EXTERNALITIES ${ }^{1,2}$}

Israel de Oliveira Andrade 3

Márcio Magno de Farias Franco e Silva ${ }^{4}$

Giovanni Roriz Lyra Hillebrand ${ }^{5}$

Luiz Gustavo Aversa Franco ${ }^{6}$

1. This text corresponds to the translation of the research, published originally in Portuguese: 0 Submarino Nuclear Brasileiro: defesa nacional e externalidades tecnológicas. Brasília: Ipea, 2019. (Texto para Discussão, n. 2428).

2. We would like to express our sincere gratitude to Admiral Bento Costa Lima Leite de Albuquerque Junior, his office and support staff, Rear Admiral André Luís Ferreira Marques, Professor Álvaro Toubes Prata, Ph.D. - State Secretary of Research \& Development Policies and Programs of the Ministry of Science, Technology, Innovation, and Communications (MCTIC) - and Professor Antonio Jorge Ramalho da Rocha, Ph.D. - University of Brasilia (UnB) - for valuable suggestions and comments that significantly improved the text, exempting them from any errors or omissions. Any remaining imperfections in the text are the sole responsibility of the authors.

3. Researcher at lpea.

4. Head of the Graduate Studies Program in Maritime Studies from Brazilian Naval War College (EGN).

5. Researcher in the National Development Research Program (PNPD) at Ipea.

6. Researcher in the PNPD at Ipea. 


\section{Federal Government of Brazil}

Ministry of Economy

Minister Paulo Guedes

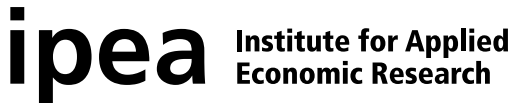

A public foundation affiliated to the Ministry of Economy, Ipea provides technical and institutional support to government actions - enabling the formulation of numerous public policies and programs for Brazilian development and makes research and studies conducted by its staff available to society.

\section{President}

Carlos von Doellinger

Director of Institutional Development

Manoel Rodrigues Junior

Director of Studies and Policies of the State, Institutions and Democracy

Flávia de Holanda Schmidt

Director of Macroeconomic Studies and Policies José Ronaldo de Castro Souza Júnior

Director of Regional, Urban and Environmental Studies and Policies

Nilo Luiz Saccaro Júnior

Director of Sectoral Studies and Policies of Innovation and Infrastructure

André Tortato Rauen

Director of Social Studies and Policies

Lenita Maria Turchi

Director of International Studies, Political

and Economic Relations

Ivan Tiago Machado Oliveira

Head of Press and Communication

Mylena Fiori

Ombudsman: http://www.ipea.gov.br/Ouvidoria

URL: http://www.ipea.gov.br

\section{DISCUSSION PAPER}

A publication to disseminate the findings of research directly or indirectly conducted by the Institute for Applied Economic Research (Ipea). Due to their relevance, they provide information to specialists and encourage contributions.

C Institute for Applied Economic Research - ipea 2020

Discussion paper / Institute for Applied Economic Research.- Brasília : Rio de Janeiro : Ipea, 1990-

ISSN 1415-4765

1. Brazil. 2. Economic Aspects. 3. Social Aspects. I. Institute for Applied Economic Research.

CDD 330.908

Ipea publications are available for free download in PDF (all) and EPUB (books and periodicals).

Access: http://www.ipea.gov.br/portal/publicacoes

The opinions expressed in this publication are of exclusive responsibility of the authors, not necessarily expressing the official views of the Institute for Applied Economic Research and the Ministry of Economy.

Reproduction of this text and the data contained within is allowed as long as the source is cited. Reproduction for commercial purposes is prohibited.

JEL: F5; H56; L64. 


\section{CONTENTS}

ABSTRACT

1 INTRODUCTION

2 AREAS OF SURVEILLANCE, PROTECTION, AND POWER PROJECTION:

BRAZILIAN JURISDICTIONAL WATERS AND BRAZILIAN

STRATEGIC ENVIRONMENT 8

3 THE DIFFERENT TYPES OF SUBMARINES AND THE

BRAZILIAN NAVY SUBMARINE FORCE.

4 THE SUBMARINE DEVELOPMENT PROGRAM AND THE BRAZILIAN

NUCLEAR-POWERED SUBMARINE

5 CONCLUSION

REFERENCES 



\section{ABSTRACT}

In order to prepare and employ naval power and contribute to national defense, the Brazilian Navy, through its programs and projects, seeks to develop means of implementation of naval war operations and actions suitable for its main tasks - sea denial and control, and power projection. A significant portion of these efforts is the Submarine Development Program (PROSUB), which the ultimate purpose is to develop the first Brazilian nuclear-powered submarine. This paper aims to emphasize the importance of PROSUB (especially regarding the nuclear submarine) to the accomplishment of the Brazilian Navy constitutional mission and to the country's development and security, notably stressing its positive externalities (in technological, human resources and social terms) and the importance of its continuity and enhancement.

Keywords: Submarine Development Program (PROSUB); Brazilian nuclear-powered submarine; national defense; geopolitics; defense industry; Defense Industrial Base (DIB); Blue Amazon; maritime power; public policies; Brazilian Navy. 



\section{Discussion}

Paper

\section{INTRODUCTION}

In addition to the sovereignty over its land territory of more than 8.5 million square kilometers, Brazil also has an extensive maritime space, over 3.5 million square kilometers which extends along its more than 7,000 kilometers of ocean coast. ${ }^{1}$ It is a vital area for the country, which has a large population concentration along the coast and enormous natural resources. It is also noteworthy that almost all Brazilian foreign trade and communication lines cross these waters, thus increasing the region's relevance for Brazil. ${ }^{2}$ Furthermore, a large portion of Brazilian foreign trade flows along the Atlantic Ocean so that specific regions abroad have strategic importance for the country - such as the Cape of Good Hope, at the southern tip of Africa, and the Drake Passage, between the Antarctic continent and South America.

In order to fulfill its mission of preparing and employing naval power to contribute to national defense, ${ }^{3}$ the Brazilian Navy (MB, acronym in Portuguese) seeks, through its strategic programs, to develop the necessary means and assets for its operations at sea, suitable for carrying out its main tasks - sea denial, the control of maritime areas, and the projection of power in a limited way. In this way, the Brazilian Navy aims to ensure the surveillance and safety of the Brazilian jurisdictional waters (AJB, acronym in Portuguese), secure national sovereignty and support foreign policy, in addition to exercising deterrence and assisting in the welfare and progress of society. A significant component of these efforts is the Submarine Development Program (PROSUB), with great emphasis on the development of the first Brazilian nuclear-powered submarine, or abbreviated as SN-BR in Portuguese. ${ }^{4}$

The PROSUB aims to meet important goals of the Brazilian "National Defense Policy", such as having a "large submarine naval force, composed of both conventional and nuclear-powered submarines" (Brazil, 2012b, p. 21, translated by the authors).

1. The Brazilian maritime space, or formally the Brazilian Jurisdictional Waters (AJB, acronym in Portuguese), can be extended to approximately 5.7 million square kilometers if Brazil's claim is fully accepted by the United Nations as presented later on in the text.

2. The Brazilian Navy created the term Blue Amazon to highlight the strategic importance of this area.

3. Brazilian Navy's mission and future vision. Retrieved Jan. 31 1 st 2018 , from: <https://goo.gl/PH64bA>.

4. Nuclear-powered submarines are generally referred to as nuclear submarines in the various means of communication. However, in the case of SN-BR, there is no connection with nuclear weapons, but only with the type of energy used in its propulsion system. 
This is a strategic program that, due to the focus on the nationalization of components developed in its different stages, has become the largest scientific-technological training program of the Brazilian defense industry (Drummond, 2017). Although its main objective is related to national defense, it should be noted that the investments made in this program produce benefits of various kinds for the Brazilian society, while also bringing substantive returns in terms of dual-use technologies (civil and military use).

The objective of this paper is to demonstrate the importance of the PROSUB, highlighting the nuclear-powered submarine, emphasizing its positive externalities and the need for its continuity and reinforcement. For this purpose, the text is divided into five sections including this introduction. Section 2 presents the main areas of Brazilian Navy's surveillance, protection, and power projection in the so-called Blue Amazon and in the South Atlantic, demonstrating the importance of its actions in these spaces and the opportunities and threats they present.

Section 3 addresses the strategic importance of submarines in naval warfare and the history of Brazilian Navy's Submarine Force, as well as a comparison of its fleet with that of other countries. Section 4 analyzes the PROSUB development and its ultimate goal of designing and building the SN-BR, highlighting the program's benefits and positive externalities, including for science, technology, and innovation (ST\&I), illustrating the direct and indirect gains for Brazil with its achievement. Finally, the conclusion presents final considerations and the results of the research, pointing out its main implications for the formulation and implementation of public policies by the Brazilian government.

\section{AREAS OF SURVEILLANCE, PROTECTION, AND POWER PROJECTION: BRAZILIAN JURISDICTIONAL WATERS AND BRAZILIAN STRATEGIC ENVIRONMENT}

The area of interest for the Brazilian Navy includes the inland waters (rivers and lakes), the entire Brazilian coast, and its adjacent area, as well as the entire "southern portion" of the Atlantic Ocean, reaching the Caribbean Sea, Antarctica, and the coasts of the African continent. This area can be understood by means of two different concepts: the Brazilian jurisdictional waters (AJB) and the Brazilian strategic environment (EEB). ${ }^{5}$

5. Acronyms in Portuguese for Águas Jurisdicionais Brasileiras (AJB) and Entorno Estratégico Brasileiro (EEB). 


\section{Discussion}

Paper

\subsection{Definitions and limits of Brazilian jurisdictional waters and Brazilian strategic environment}

The AJB constitute the priority area of action of the Brazilian Navy. It is an area of approximately 3.5 million square kilometers, with the possibility of an extension for up to approximately 5.7 million square kilometers, ${ }^{6}$ as will be indicated below. The delimitation of this extensive space follows the standards and concepts of the United Nations Convention on the Law of the Sea (UNCLOS), which geophysically organizes maritime spaces into four main segments: $i$ ) the territorial sea; $i$ i) the contiguous zone; iii) the exclusive economic zone (EEZ); and iv) the continental shelf (CS).

First, the territorial sea is defined by UNCLOS as "an adjacent sea area" in which "the sovereignty of a coastal State extends beyond its land territory and internal waters", including the air space above, the seabed, and the sea subsoil (Brazil, 1995, art. 2, paragraphs 1 and 2). Its limit is up to 12 nautical miles (NM) measured from the "baselines" (Brazil, 1995, art. 3). ${ }^{7}$ Within the limit of $24 \mathrm{NM}$ from the baselines lies the contiguous zone, a space in which "the coastal State may exercise the control necessary" to prevent and punish "infringement of its customs, fiscal, immigration or sanitary laws and regulations within its territory or territorial sea” (Brazil, 1995, art. 33).

Within the limit of 200 NM from the baselines, there is the EEZ (Brazil, 1995, art. 57), "an area beyond and adjacent to the territorial sea", regulated by a "specific legal regime" that establishes "the rights and jurisdiction of the coastal State and the rights and freedoms of other States" (Brazil, 1995, art. 55). In this area, the coastal State has "sovereign rights for the purpose of exploring and exploiting, conserving and managing the natural resources, whether living or non-living, of the waters superjacent to the seabed and of the seabed and its subsoil", as well as rights of "economic exploitation and exploration of the zone" (Brazil, 1995, art. 56, paragraph 1, “a”).

Finally, the convention defines the continental shelf of a coastal State as "the seabed and subsoil of the submarine areas that extend beyond its territorial sea throughout the natural prolongation of its land territory to the outer edge of the continental margin" (Brazil, 1995, art. 76, paragraph 1).

6. This information was updated for this version of the text, in view of new claims made after the publication of the original paper.

7. The definitions and possible methods of determining these lines by the coastal State can be found in Articles 4, 5, 7 and 14 of UNCLOS. 
UNCLOS also provides for the possibility of extending the limits of the CS beyond 200 miles through the submission of information by the coastal State to the Commission on the Limits of the Continental Shelf (CLCS), "on the basis of equitable geographical representation" (Brazil, 1995, art. 76, paragraph 8). In this space, the coastal State "exercises over the continental shelf sovereign rights for the purpose of exploring it and exploiting its natural resources" (Brazil, 1995, art. 77). ${ }^{8}$

The document also states that "the outer limit of the continental shelf shall not exceed 350 nautical miles from the baselines from which the breadth of the territorial sea is measured" (Brazil, 1995, art. 76, paragraph 6). ${ }^{9}$ Thus, in order for Brazil to be able to claim jurisdiction over this extended area of the continental shelf, situated beyond the 200 NM and limited by the 350 NM stipulated by UNCLOS, the Brazilian government implemented, with the Brazilian Navy as a participant, the Continental Shelf Survey Plan (LEPLAC, acronym in Portuguese), which developed a series of seabed surveys that supported the Brazilian proposals of extending its CS.

The Brazilian CS now extends beyond the 200 nautical miles at various points, which include natural and mineral resources of vital strategic importance. Therefore, since 1989, by means of LEPLAC, the Brazilian government has been carrying out technical and scientific analyses in order to expand its continental shelf. Since 2004, the Brazilian government has formally submitted to the CLCS requests to extend its platform. This extended area, together with the Brazilian EEZ, would cause the AJB to reach aapproximately 5.7 million square kilometers, which is equivalent to more than half of Brazil's continental territory.

Based on the provisions of UNCLOS and in full compliance with its rules, the Brazilian State delimited the AJB under Law No. 8.617 of January $4^{\text {th }}, 1993$, and on Decree No. 1.530 of June $22^{\text {nd }}$, 1995. The geographical division of these spaces can be seen in figure 1, which also shows the area that represents the Brazilian proposal for extending its CS.

8. These include "the mineral and other non-living resources of the seabed and subsoil together with living organisms belonging to sedentary species, that is to say, organisms which, at the harvestable stage, either are immobile on or under the seabed or are unable to move except in constant physical contact with the seabed or the subsoil" (Brazil, 1995, art. 77, paragraph 4).

9. The parameters to define precisely the limits of the continental shelf are presented in art. 76 , paragraphs 4 and 5. 


\section{Discussion}

Paper

FIGURE 1

Geographical demarcation of the Brazilian maritime spaces

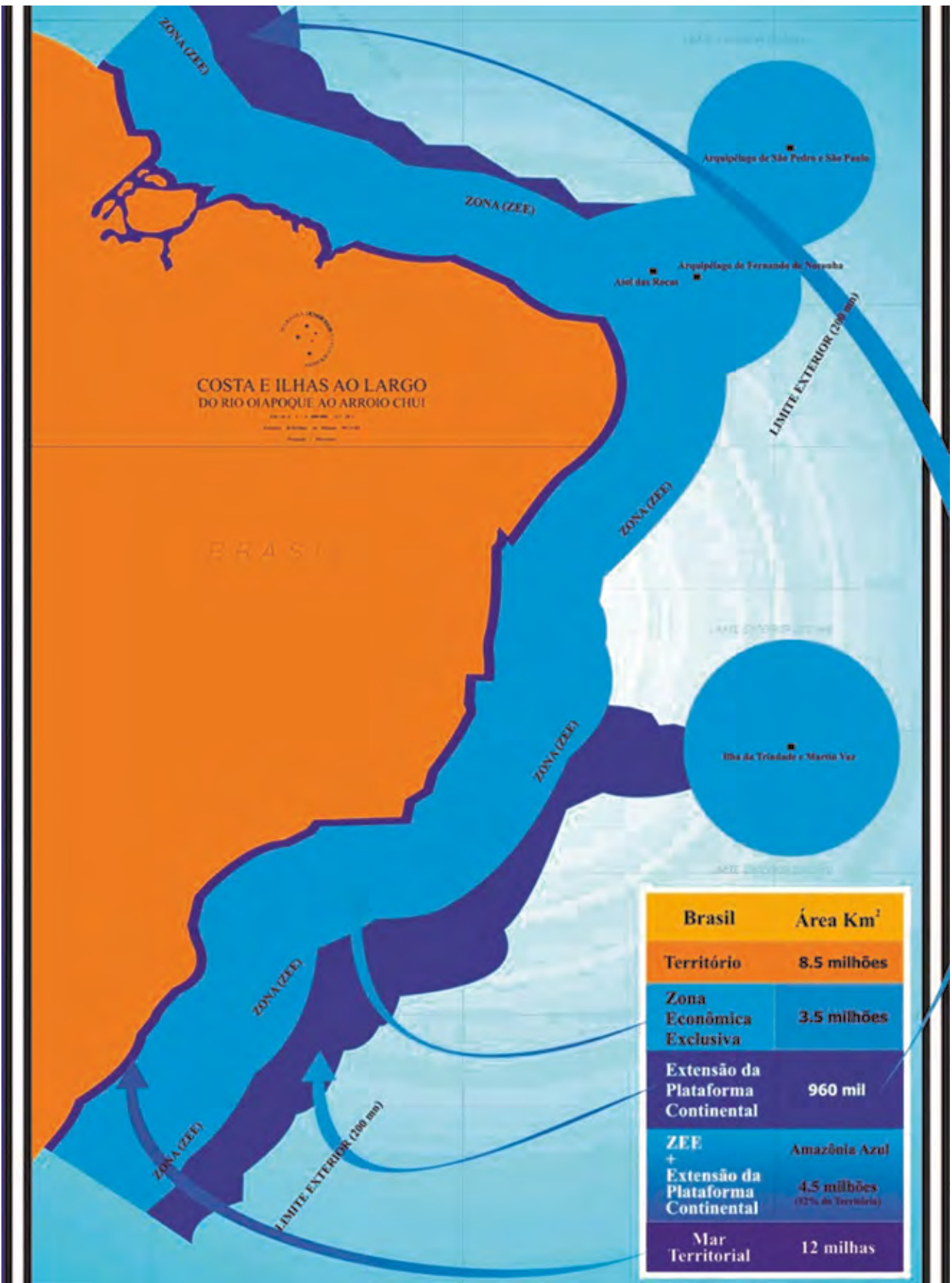

Source: Brazilian Navy. 
In this regard, Law No. 8.617/1993 refers to the demarcation of maritime spaces, to the prerogatives, and to the rights and duties of Brazil as a coastal State, in addition to bringing important devices for managing the AJB. In relation to the territorial sea, the law guarantees "the right of innocent passage of foreign vessels", ${ }^{10}$ but those vessels shall be "subject to regulations established by the Brazilian government" (Brazil, 1993, art. 3). With regards to the EEZ, the law establishes that "marine scientific research (...) can only be conducted by other States with the prior consent of the Brazilian government, in compliance with the relevant legislation" (Brazil, 1993, art. 8, sole paragraph) and that the "performance by other states (...) of military exercises or maneuvers, in particular those involving the use of weapons or explosives, may only occur with the consent of the Brazilian government" (Brazil, 1993, art. 9).

As concerns the Brazilian CS, the law determines that "marine scientific research (...) can only be conducted by other states with the prior consent of the Brazilian government, in compliance with the relevant legislation", being that the "Brazilian government shall have the exclusive right to authorize and regulate drilling on the continental shelf, whatever its purposes" (Brazil, 1993, art. 13). In addition, by law, "tracing the line for laying" submarine cables and pipelines on the shelf "depends on the consent of the Brazilian government", which "may establish conditions for the laying of cables and pipelines entering its territory or territorial sea" (Brazil, 1993, art. 14).

Still in relation to the proposal of extending its CS, three years after the first submission, the Brazilian government received a response from the CLCS with the request partially granted, motivated by the challenge of this commission of approximately 190,000 square kilometers of areas. Such partial denial, however, does not preclude Brazil from exercising its sovereign rights and prerogatives over this area (Figueirôa, 2014). ${ }^{11}$

In addition to the AJB, another area of great importance for Brazil and of interest to the Brazilian Navy, especially with respect to power projection and protection of national interests, is the Brazilian strategic environment (EEB). According to the

10. "The passage shall be considered innocent so long as it is not prejudicial to the peace, good order, or security of Brazil, and should be continuous and expeditious" (Brazil, 1993, art. 3, paragraph 1).

11. According to Figueirôa (2014, p. 234, translated by the authors), "the procedure in the Commission allows the outer limits of the continental shelf to become definitive and binding before other States, but does not imply that Brazil or any other coastal State can exercise its sovereign rights only after this". 
"National Defense Policy" (PND, acronym in Portuguese), this area "extrapolates the South American region and includes the South Atlantic and the countries on the coast of Africa, as well as Antarctica". Furthermore, "to the north, the proximity with the Caribbean Sea imposes growing attention to this region” (Brazil, 2012b, p. 21).

In reading this document, one can notice that the South Atlantic, along with the Brazilian Amazon, is part of the "priority areas for national defense", in addition to the core regions of political and economic powers (Brasília and the industrial conglomerate of São Paulo and Rio de Janeiro, respectively) (Silva, 2012, p. 14). In the words of the then Commander of the Brazilian Navy, Admiral Eduardo Bacellar Leal Ferreira, "[the] South Atlantic, much more than a simple communication bridge with the rest of the world, represents the inexorable pathway for Brazilian economic and social growth" (Ferreira, 2017, p. 2-3, translated by the authors).

The South Atlantic, considered a "primary area" for the Brazilian Navy, is defined as "the maritime region between parallel $16^{\circ} \mathrm{N}$, the west coast of Africa, the Antarctic continent, and the east coast of South America", and Brazil holds "an outstanding geostrategic position of this vast ocean" (Silva, 2012, p. 13). In accordance with the Brazilian "Defense White Paper" (LBDN, acronym in Portuguese), Brazil has "special interest in South Atlantic peace and security", region that includes "relevant strategic areas, such as the 'Atlantic Throat', the area between the Brazilian Northeast Coast and Western Africa", "the southern passages, which link the Atlantic to the Pacific", and "the Cape of Good Hope", that connects "the South Atlantic to the Indian Ocean" (Brazil, 2012a, p. 38). Furthermore, according to Silva (2012, p. 13, translated by the authors), "the national vulnerability that will take on greater importance in the middle of this $21^{\text {st }}$ century will be the distant maritime borders in the South Atlantic", which emphasizes the strategic importance of this extensive oceanic region.

As for Antarctica, "a continent adjacent to the South Atlantic with influences on Brazilian climate" and "region of interest and global political importance", there are strategic and scientific concerns on the part of Brazil "due to the potential of that remote region" (Silva, 2012, p. 42, translated by the authors). ${ }^{12}$

12. For more information about the Brazilian Antarctic Program (Proantar) and Brazil's performance in that continent, see Andrade et al., 2018 (Texto para Discussão, no. 2425) and Andrade et al., 2020 (Discussion Paper, no. 251). 


\subsection{Opportunities and threats of the Brazilian jurisdictional waters and the Brazilian strategic environment}

The vast area comprised by the EEB has several assets (population centers, mineral resources, natural riches, communication lines etc.) to be protected, in addition to risks to be managed and mitigated. The existence of such opportunities and threats justifies the presence and surveillance by the Brazilian Navy in these areas, reinforcing the importance of providing for this Force adequate means of action.

A relevant characteristic that should be observed is the strong concentration of population along the country's coast. According to the Brazilian Institute of Geography and Statistics (IBGE, acronym in Portuguese), approximately $80 \%$ of the Brazilian population is located along a strip of land up to $200 \mathrm{~km}$ from the coast. Map 1 illustrates this aspect.

MAP 1

Brazilian demographic density (2010)

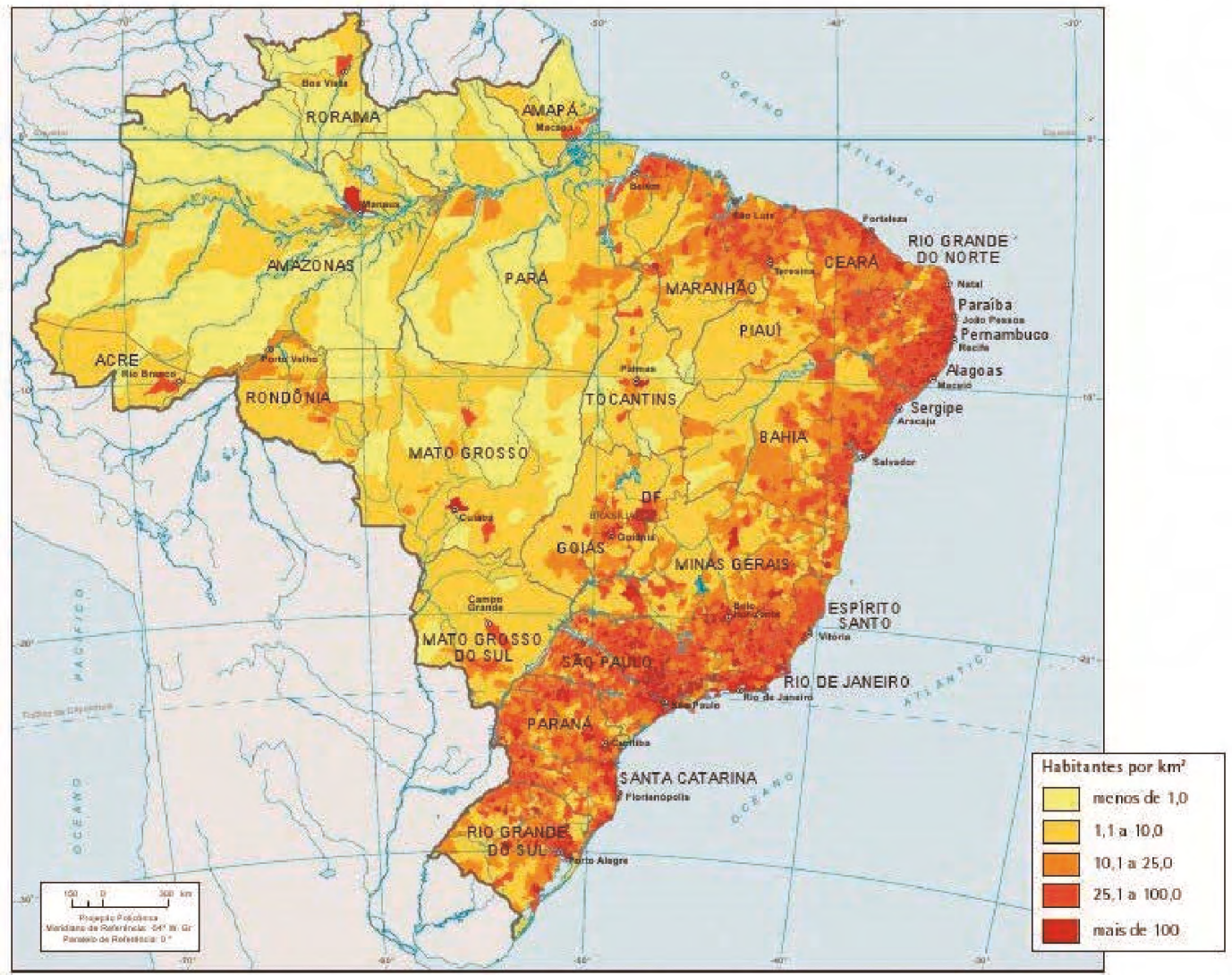

Source: IBGE. Retrieved from: <https://goo.gl/heSTaS>

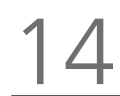


Moreover, approximately $90 \%$ of Brazilian industry production and infrastructure, as well as around $80 \%$ of the domestic product, is concentrated in this same area. This alone constitutes "considerable vulnerability", which in turn, "emphasizes the need for protecting this vital Brazilian area" (Silva, 2012, p. 14, translated by the authors). Another potentiality of the AJB relates to the natural resources found in them, especially the oil and natural gas reserves, as will be highlighted below.

Approximately $90 \%$ of the country's oil production (a little more than 2 million barrels per day) comes from the CS with some new fields located close to the limit of 200 nautical miles from the baselines (Silva, 2012). In 2002, the national reserves of these resources totaled 9.81 billion barrels with 8.87 billion coming from AJB. ${ }^{13}$ These volumes grew even more with the discovery of reserves in the pre-salt layer. Not coincidentally, $89.04 \%$ of the country's oil and $76.12 \%{ }^{14}$ of its natural gas comes from maritime fields (Brazil, 2016).

In production for 10 years and with 21 platforms in operation, the Brazilian presalt layer reached in 2017 the mark of 1.5 million barrels of oil per day. It is projected that the pre-salt production will grow until 2022 with progressive investments and with the implementation of another 13 platforms. A significant fact is that the 36 most productive wells in Brazil are located in the pre-salt layer, and it is estimated that for every four projects from Petrobras in the coming years, three will be installed in this layer, reaffirming the importance of the Brazilian seabed. ${ }^{15}$ In this context, the Brazilian National Agency of Petroleum, Natural Gas and Biofuels (ANP, acronym in Portuguese) estimates that approximately US\$ 83 billion will be generated in direct investments and US\$ 125 billion in indirect investments in the oil and natural gas sector in the coming years, counting on the economic recovery of the sector.

Therefore, there is a "strategic importance of the petroleum industry in open sea and the logistics that support it (...) as a very relevant part of national maritime power" (Silva, 2012, p. 42, translated by the authors). Considering this, one of the Brazilian Navy's tasks that stands out is to ensure the protection of the regional maritime communication lines, as well as the physical integrity of the offshore platforms, submarine cables, pipelines, ships, ports, and facilities, which are structural maritime instruments.

13. Brazilian Navy. Economic aspect. Retrieved Dec. 21'st, 2017, from: <https://goo.gl/gMdkkq>.

14. Averages for the first quarter of 2016 according to data from the National Agency of Petroleum, Natural Gas, and Biofuels (ANP).

15. For more information, access: <https://goo.gl/6vmpFy>. 
Another fundamental characteristic of the AJB is the maritime routes that cross these waters, providing most of the country's foreign trade flow. According to the National Agency for Waterway Transportation (ANTAQ, acronym in Portuguese), 25 of the 35 major Brazilian ports are located on the coast. ${ }^{16}$ Furthermore, approximately 95\% of Brazil's foreign trade passes through these sea routes (Arruda, 2014, p. 41-42). Figure 2 illustrates the main sea foreign trade communication lines from Brazil.

\section{FIGURE 2}

Maritime communication lines of the Brazilian foreign trade

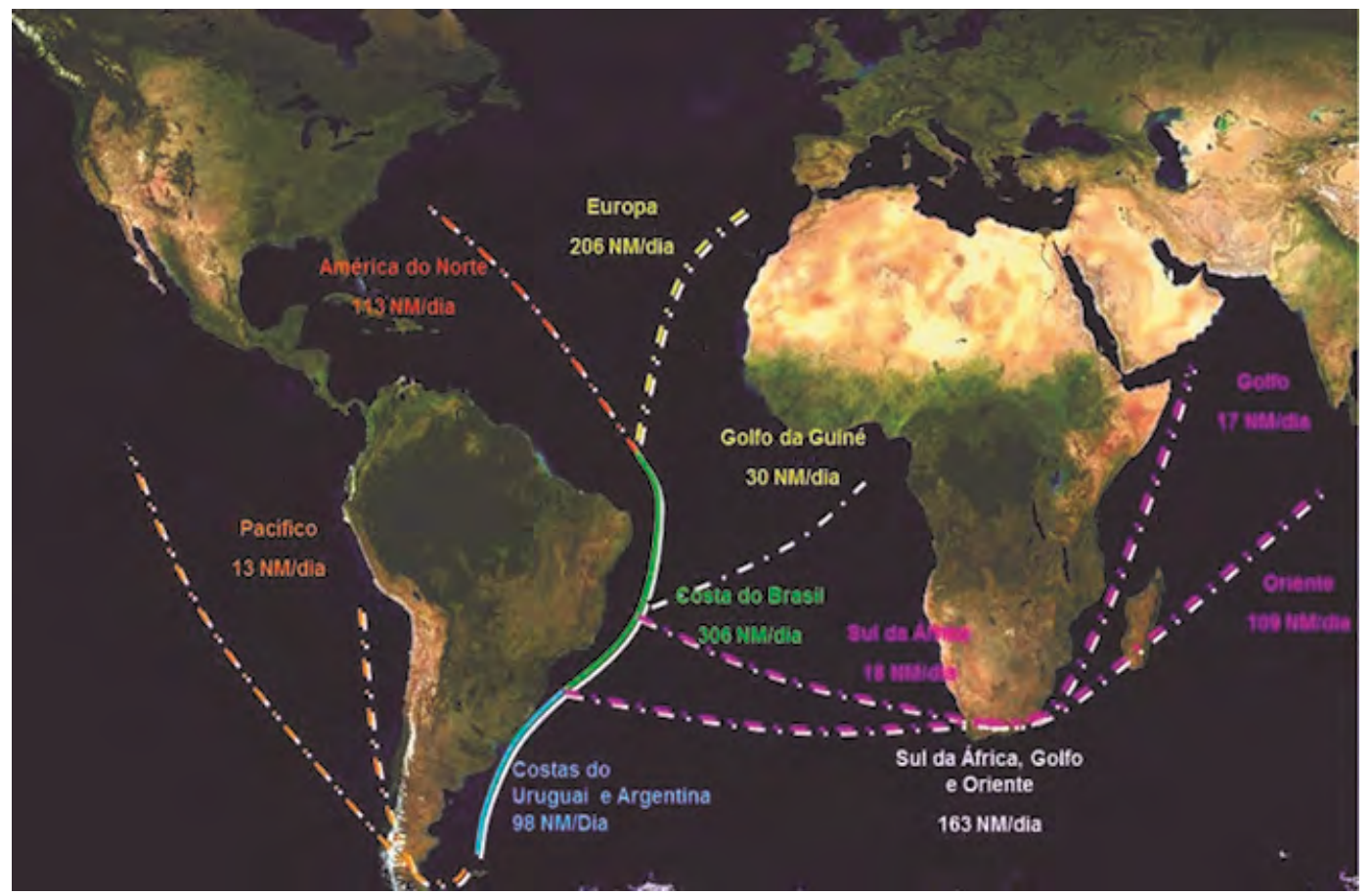

Source: Arruda (2014, p. 41).

Preparation: Julio Soares Moura Neto.

The fact that almost all Brazilian foreign trade is carried along South Atlantic routes reinforces its importance, as well as emphasizes another of the country's vulnerabilities: "the full dependence of maritime communications lines" for its commercial trade. The interruption and/or obstruction of these lines, that is, the "loss

16. Notice that there are ports in the inland of Brazilian territory such as Porto Velho-RO, Manaus-AM, and Santarém-PA. Even though they are not on the coast, these ports can also be maritime (able to receive oceanic navigation lines), only fluvial (which communicate with other national ports through inland waters), or even lacustrine (which receive vessels inside lakes or restricted reservoirs, without communication with other basins). 
of control of maritime traffic", may prove to be "disastrous for the national economy" (Silva, 2012, p. 14, translated by the authors), further strengthening the importance of the presence of the Brazilian Navy in those distant maritime spaces.

Another component of interest to Brazil in its strategic environment is the group of African countries located along the Atlantic coast. The main ones are as follows: Angola, Cape Verde, Equatorial Guinea, Guinea Bissau, Namibia, Nigeria, São Tomé and Príncipe and South Africa. In this set, South Africa holds high importance due to its political-strategic and economic dimensions. Furthermore, this country has an important geographical position in the South Atlantic Ocean, which makes the connection between the Atlantic and Indian Oceans and where a large part of the trade volume coming from and destined to Brazil passes through (Silva, 2012). Angola should also be highlighted, especially due to its strong historical ties with Brazil. Within this context, Nigeria also stands out because of it being a large exporter of hydrocarbons to Brazil and because its gross domestic product rivals that of South Africa.

Furthermore, Namibia is another African country with which Brazil maintains important political and military cooperation and with whom the bilateral relationship has been shown to be of considerable importance to the strategic presence in that continent. Its ties with Brazil are largely related to the fact that the Brazilian Navy has taken action in setting up and training the navy of this country after its independence in $1990 .{ }^{17}$

Brazil has naval cooperation projects at different degrees with Angola, Cape Verde, Mozambique, ${ }^{18}$ São Tomé and Príncipe, Senegal, and South Africa. ${ }^{19}$ In relation to national interests, the geopolitical importance of the maritime region of the Gulf of

17. The Brazilian naval cooperation with Namibia is of extreme importance to that country because "in addition to the continued training of personnel, the Brazilian government has donated and sold vessels to the Namibian Navy while also preparing a hydrographic survey of the port of Walvis Bay and delivered the nautical chart to the Namibian authorities". Furthermore, the Brazilian Navy has "two support groups in Walvis Bay, one for training marines and the other for supporting the maintenance of Namibian Navy's vessels" (Penna Filho, 2015, p. 165, translated by the authors).

18. Although Mozambique is not located on the Atlantic coast of Africa, it is among the priority countries for Brazilian foreign policy because it is a part of the Community of Portuguese Language Countries (CPLP, acronym in Portuguese) together with Brazil, Angola, Cape Verde, Equatorial Guinea, Guinea Bissau, Portugal, São Tomé and Príncipe, and the distant East Timor. 19. These programs are "broad and varied" and include "the exchange on vessels of the Brazilian Navy and in operational bodies, visits to science and technology organizations, naval bases, and instruction and training centers," along with "advising in various areas, such as the acquisition of ships, equipment, uniforms, and related items" (Penna Filho, 2015, p. 166). For a detailed examination of Brazilian cooperation with these countries, see Abdenur and Souza Neto (2014). 
Guinea stands out for being rich in oil and gas and whose production "begins to compete with that of the Middle East" (Paiva, 2015, p. 193, translated by the authors), although with a lower level of governance.

The west coast of Africa is considered "the most vulnerable side of the South Atlantic", ${ }^{20}$ and "the growth of maritime insecurity and the difficulties encountered mainly by the African States" in addressing this situation has been "one of the aspects that has called the attention of countries that are not part of the South Atlantic to the region". In this regard, the "increase in piracy, drug trafficking, illegal fishing, and other illicit activities in the waters of the Atlantic Ocean" is seen as a great challenge for African countries, "since most of them do not have the minimum conditions to confront these threats" (Penna Filho, 2015, p. 164-165, translated by the authors).

A further element of cooperation that permeates the action of the Brazilian Navy in the region is the South Atlantic Peace and Cooperation Zone (ZOPACAS, acronym in Portuguese), an international forum of high diplomatic importance within the Brazilian strategic environment. It is a forum for increasing interaction and mutual support among the South Atlantic States, being one of the arenas for dialogue on security issues between these countries. Established in 1986 as the result of a Brazilian diplomatic initiative, ZOPACAS consists of the following countries apart from Brazil: Angola, Argentina, Benin, Cape Verde, Cameroon, Congo, Democratic Republic of the Congo, Equatorial Guinea, Gabon, Gambia, Ghana, Guinea, Guinea-Bissau, Ivory Coast, Liberia, Namibia, Nigeria, São Tomé and Príncipe, Senegal, Sierra Leone, South Africa, Togo, and Uruguay. ${ }^{21}$

Although there is considerable closeness and complementarity among its members, ZOPACAS suffers from huge asymmetries. Notably, among all 24 navies of the group, the Brazilian Navy is the one that presents itself with greater expressiveness, flexibility, and presence in the South Atlantic region. Some of the Member States, particularly those in Africa, "have only nominal Defense Navies and are unable to deal with the growth of

20. According to Penna Filho $(2015$, p. 180 , translated by the authors), many of the tensions along the African Atlantic coast are concentrated "mainly in the large oil zone of the Gulf of Guinea", where "there has been a significant increase in criminal activities, such as the action of pirates and similar actions, which has led to a feeling of strong maritime insecurity throughout the region with economic and political impacts for the countries in that area."

21. South Atlantic Peace and Cooperation Zone. Retrieved Jan. 11th 2018 , from: <https://goo.gl/txapir>. 
criminal activities that bring insecurities to their territorial waters" (Penna Filho, 2015, p. 160, translated by the authors). This framework also reinforces the importance of the presence and activity of the Brazilian Navy in the region, so that the strengthening of ZOPACAS is important for the country's defense" (Brazil, 2012b, p. 39).

Along with the various national interests and opportunities present in the AJB and EEB, a number of risks and threats can also be identified in these spaces. Faria (2011, p. 23) lists some of the major Brazilian vulnerabilities in these regions: $i$ ) concentration of oil production at sea without an effective defense system; $i$ ) concentration of large cities and of productive and energy systems along the coast; iii) the foreign trade is dependent on extensive communication lines; and $i v$ ) the existence of oceanic islands without a defense system. An emphasis should also be added to the threats posed by transnational illicit activities (piracy, trafficking, smuggling), as well as the need to ensure the security of natural resources in the national waters and strategic environment.

The importance of mitigating the risks and combating the threats in these areas is demonstrated in the Brazilian "National Defense Strategy" (END, acronym in Portuguese), which, in reference to the Navy's strategic objectives, states that "sea denial, the control of maritime areas, and the projection of power must be focused on (...) readiness to respond to any threat, whether by States or by non-conventional or criminal forces, to the maritime routes of trade" (Brazil, 2012b, p. 69).

Based on the scenario depicted, it is possible to observe that Brazil is presented with "a great dependence on the Atlantic (...) for the export and import of products", so that "the guarantee of free navigation becomes essential for the country's continuous development" (Penna Filho, 2015, p. 168-169, translated by the authors). Therefore, it is necessary for Brazil to maintain maritime safety in national waters and to remain present in the areas of national interest, especially considering the EEB.

\section{THE DIFFERENT TYPES OF SUBMARINES AND THE BRAZILIAN NAVY SUBMARINE FORCE}

The history of submarines dates back to the $16^{\text {th }}$ century when the Englishman William Bourne described the principle by which a ship could submerge and return to the water's surface by controlling its volume and weight. Among the various experiments conducted 
since then, we can highlight some milestones in respect to their military use: in 1776, in the context of the United States' independence, the American Turtle was the first underwater vehicle to carry out an attack on an enemy ship; in 1864, during the civil war in that same country, the CSS H. L. Hunley became the first submarine to sink an enemy ship of war, even though it disappeared soon after the successful offensive (Harris, 2016).

The massification process in using submarines started at the end of the $19^{\text {th }}$ century, with its widespread employment especially since World War I (1914-1918). The great difficulty of being detected gives the submarine the initiative of attack, which makes it the main means of deterrence in the naval environment (Pinto, 1989; Silva, 2012). The mere existence of a submarine force by a country causes the other nations, especially in the event of war, to be forced to reorganize their naval resources and to restructure their sea operations strategy. Submarines are vessels that have great power of destruction, usually by means of torpedoes, and can attack from a long distance and with high accuracy targets on land or other ships - or even other submarines (Zimmerman, 1990).

\subsection{Types of submarines in accordance with their propulsion system}

Currently, different categories of submarines are developed, according to their function and type of propulsion. Considering the scope of this paper, only those of a military nature will be in accordance with the propulsion technology used: conventional diesel-electric or air-independent propulsion (AIP) - or nuclear-powered.

Designated as conventional are the diesel-electric propulsion submarines, which represent the largest part of the submarine fleets around the globe. Their diesel engines, when activated, charge energy accumulators (batteries) that feed the propulsion system and the equipment necessary for the submarine's operation.

Conventional submarines periodically need to emerge to a depth considered safe, close to the surface, to recharge their batteries, and even if recharging occurs with the use of a snorkel, ${ }^{22}$ this makes them vulnerable and compromises their main characteristic - its hiding

22. The snorkel is a hybrid system of a conventional submarine that has the objective to absorb atmospheric air without the need of the submarine fully emerging to the surface. The system intakes the oxygen needed for the operation of the combustion engines, making it possible to transform potential energy into electricity and recharge the batteries that activate the electric propulsion system. 
potential. In order to eliminate the greatest vulnerability of a conventional submarine, which is being air dependent, the United States developed a form of propulsion based on another type of energy, and launched into the sea in 1954 the submarine USS Nautilus, the first nuclear-powered submarine of the globe (Hoffman, 2018).

In the midst of the nuclear race that took place between the North-Americans and Soviets throughout the Cold War (1945-1991), it was noticed that atomic energy could be applied to submarines. In this case, the nuclear-powered submarine has a nuclear power reactor that does the fissioning of uranium, resulting in a large and constant release of heat that triggers the entire energy transformation process and culminates in the activation of the propulsors. This type of submarine, therefore, can stay submerged for virtually unlimited time since the energy generation capacity of the reactor allows navigation for hundreds of thousands of kilometers with just a few kilograms of uranium fuel. The factors that may limit the submersion period of a nuclear-powered submarine are, therefore, the physical resistance of the crew, the refueling of supplies, and possible malfunctions.

The main advantage of nuclear-powered submarines is their great autonomy, which allows them to remain submerged throughout an entire mission, while conventional submarines need to return to snorkel depth periodically, leaving traces of smoke and heat and therefore becoming vulnerable to detection. Furthermore, the nuclear propulsion allows reaching higher speeds: at least $25 \mathrm{knots}(46.3 \mathrm{~km} / \mathrm{h})^{23}$ when submerged, while the majority of current nuclear-powered submarines can reach speeds exceeding 30 knots $(55.5$ $\mathrm{km} / \mathrm{h}$ ). High speeds, however, generate a lot of noise during travel, as well as compromise the submarine's sonar detection system. As for the diesel-electric propulsion submarines, on the other hand, the maximum speed depends on the capacity of their batteries. Some models of conventional submarines reach a little more than 20 knots $(37 \mathrm{~km} / \mathrm{h})$ when submerged. However, the higher the speed, the battery capacity decreases and the time under water is reduced, making it necessary to soon recharge the batteries (Galante, 2013).

The higher speed maintained by the nuclear-powered submarine makes this type to be suitable for missions of sea denial, as well as escorting and monitoring surface vessel convoys and task forces. In these activities, submarines can navigate short distances under the vessels

23. The "knot" is a speed measurement unit equivalent to one nautical mile per hour. It is used mainly for measurements related to maritime navigation and aviation. 
in a way that its high noise level is buffered by the water. Furthermore, due to their greater autonomy and capacity to remain isolated at sea, these types of submarines can navigate greater distances from their support bases and from the territorial coasts, which offers them a greater variety of missions in which they can act (Silva, 2012).

Another advantage of nuclear-powered submarines refers to the maximum depth reached. Because they are larger and structurally stronger in order to accommodate the nuclear reactor, these submarines have greater immersion capacity and on average can remain operational at a depth of more than 300 meters. Conventional submarines, on the other hand, maintain operational up to a depth of approximately 250 meters (Galante, 2013).

Still regarding the comparison between nuclear-powered submarines and conventional ones, the latter stand out positively in certain characteristics. The cost of acquisition or construction of a conventional submarine, for example, can be up to four times lower than that of a nuclear-powered one.

If considered their life cycle costs of training, maintenance, and decommissioning, the difference increases even more, and can reach up to ten times. Furthermore, conventional submarines are less noisy than nuclear-powered ones and are almost imperceptible at a low speed, normally used when on patrol. In nuclear-powered submarines, the pumps that circulate the liquid coolants to the reactor, as well as other equipment unique to these submarines, cause them to emit a characteristic noise during their operation, facilitating not only their detection but also their classification as a nuclear-powered submarine (Silva, 2012).

An air-independent propulsion (AIP) system has been developed in order to increase the autonomy of conventional submarines. With the purpose of preventing these submarines from needing to constantly emerge to recharge their batteries, the AIP system is designed with additional sources of energy beyond the diesel engine. In this way, the submarines designed with this technology, which may be included in the vessel at the time of its construction or deployed later, have the ability to remain submerged for weeks, depending on their speed (NRP, 2016)..$^{24}$

24. In 2006, for example, a German U-32 submarine equipped with an AIP system traveled about 2,800 km submerged, while the conventional submarines without this technology reach on average between $500 \mathrm{~km}$ and $800 \mathrm{~km}$ until they need to recharge their batteries (NRP, 2016). 
Given the differences between the main types of submarines currently used, the next section will analyze the current Brazilian Submarine Force, considering its history and perspectives.

\subsection{The Brazilian Submarine Force and its prospects}

The end of the $19^{\text {th }}$ century and the beginning of the $20^{\text {th }}$ century were marked by discussions that culminated in Brazil acquiring its first submarines. Publications in periodicals at the time by Lieutenant Felinto Perry highlighted the value of this naval device, encouraging their purchase by the Brazilian Navy and arousing the reflection of society and public administration on the subject. A naval equipping program was carried in the 1900s, stimulated by the favorable vision toward the Armed Forces and due to the Navy having personalities in their favor such as the politician and diplomat Ruy Barbosa, the minister of Foreign Affairs José Maria da Silva Paranhos (Baron of Rio Branco), and Congressman Laurindo Pitta (Wiltgen, 2016; Galante and Martini, 2014).

Part of the naval program was the acquisition of submersibles, which began to materialize in 1911 when the then minister of the Navy, Vice Admiral Joaquim Marques Baptista de Leão, created the Naval Subcommittee headquartered in La Spezia, Italy, with the aim of supervising the construction of three "Foca" (or "F") class submersibles ordered from the European country. Felinto Perry, reaching the level of Lieutenant Commander at the time, was appointed to lead the group for receiving the submersibles. The three units were incorporated between 1913 and 1914 on the eve of the outbreak of World War I. Even though small and of a reduced combat ability, these warships were important to introduce the Brazilian Navy into the context of submarines and to prepare it for the first Brazilian generation of submariners (Wiltgen, 2016; Galante and Martini, 2014).

The Submersibles Fleet was created on July 17, 1914, being administratively subordinated to the Mobile Defense Command and operationally subordinated to the Chief of Staff of the Navy. At that point began the preparations for the operation of the School of Submersibles and Underwater Weapons, with the first class of Brazilian submarine officers graduating in 1915. In 1917, the Brazilian Navy received the "Ceara" tender vessel, which was incorporated into its fleet to serve as a mobile support base for the submersibles and it also became the headquarters of the School of Submersibles (Galante and Martini, 2014; Brazil, 2014a). 
With a diesel-electric propulsion, the submersibles "F1", "F3", and "F5" reached a maximum speed of 13.5 knots $(25 \mathrm{~km} / \mathrm{h})$ at the surface and 8.5 knots $(15.7 \mathrm{~km} / \mathrm{h})$ when submerged, with a maximum immersion depth of approximately 40 meters. The vessels carried a crew of 23 men and had two types of torpedoes in their bow, being able to carry up to four units of this type of weaponry. The main tasks related to those types of submersibles were focused on training the crew and in handling and maintaining the equipment. Beginning with Brazil's involvement in World War I at the end of 1917, the fleet began to also carry out surveillance patrols in the vicinity of the port of Rio de Janeiro (Galante and Martini, 2014).

With Decree No. 18.365 of August 22 nd 1928 , the Submersibles Fleet and the School of Submersibles and Underwater Weapons had their names changed to Submarine Fleet and School of Submarines, respectively (Brazil, 1928). The name was changed again in 1963 to what prevails today - Submarine Force.

In the same year, Decree No. 52.738 was promulgated, regulating the School of Submarines and making it an autonomous body within the structure of the Brazilian Navy (Wiltgen, 2016; Brazil, 1963). Along its more than one hundred years of existence, the Brazilian Submarine Force has had several vessels, as shown in table 1.

TABLE 1

Submarines incorporated by the Brazilian Navy

\begin{tabular}{llccc}
\hline Name & \multicolumn{1}{c}{ Class } & Construction site & Incorporation & Decommissioning \\
\hline F1 & Foca & Italy & $12 / 11 / 1913$ & $12 / 30 / 1933$ \\
F3 & Foca & Italy & $3 / 16 / 1914$ & $12 / 30 / 1933$ \\
F5 & Foca & Italy & $6 / 6 / 1914$ & $12 / 30 / 1933$ \\
SE Humaytá & Balilla & Italy & $7 / 20 / 1929$ & $11 / 25 / 1950$ \\
Tupy (T-1) & Perla & Italy & $10 / 10 / 1937$ & $8 / 26 / 1959$ \\
Tymbira (T-2) & Perla & Italy & $10 / 10 / 1937$ & $8 / 26 / 1959$ \\
Tamoyo (T-3) & Perla & Italy & $10 / 10 / 1937$ & $8 / 26 / 1959$ \\
Humaitá (S14) & Gato or Fleet Type I & USA & $1 / 18 / 1957$ & $10 / 2 / 1967$ \\
Riachuelo (S15) & Gato or Fleet Type I & USA & $1 / 18 / 1957$ & $10 / 14 / 1966$ \\
Rio Grande do Sul (S11) & Balao or Fleet Type II & USA & $5 / 2 / 1972$ \\
Bahia (S12) & Balao or Fleet Type II & USA & $9 / 7 / 1963$ & $1 / 19 / 1973$ \\
Rio Grande do Sul (S11) & GUPPY II & USA & $5 / 13 / 1972$ & $11 / 16 / 1978$ \\
Rio de Janeiro (S13) & GUPPY II & USA & $7 / 8 / 1972$ & $11 / 16 / 1978$ \\
\hline
\end{tabular}




\section{Discussion}

\section{Paper}

252 Brazilian Nuclear-Powered Submarine: national defense and technological externalities

\begin{tabular}{|c|c|c|c|c|}
\hline Name & Class & Construction site & Incorporation & Decommissioning \\
\hline Guanabara (S10) & GUPPY II & USA & $7 / 28 / 1972$ & 10/10/1983 \\
\hline Bahia (S12) & GUPPY II & USA & 3/27/1973 & 7/14/1993 \\
\hline Ceará (S14) & GUPPY ॥ & USA & 10/17/1973 & $12 / 21 / 1987$ \\
\hline Goiás (S15) & GUPPY III & USA & 10/15/1973 & 4/16/1990 \\
\hline Amazonas (S16) & GUPPY III & USA & 12/19/1973 & 8/1/1992 \\
\hline Humaitá (S20) & Oberon & England & 6/18/1973 & 4/8/1996 \\
\hline Tonelero (S21) & Oberon & England & 12/10/1977 & $6 / 21 / 2001$ \\
\hline Riachuelo (\$22) & Oberon & England & 3/12/1977 & $11 / 12 / 1997$ \\
\hline Tupi (\$30) & Tupi & Germany & $5 / 6 / 1989$ & Active \\
\hline Tamoio (S31) & Tupi & Brazil & $12 / 12 / 1994$ & Active \\
\hline Timbira (S32) & Tupi & Brazil & 12/16/1996 & Active \\
\hline Tapajó (S33) & Tupi & Brazil & 12/21/1999 & Active \\
\hline Tikuna (S34) & Tikuna & Brazil & $12 / 16 / 2005$ & Active \\
\hline
\end{tabular}

Sources: Galante and Martini (2018); NGB (2018); Brazilian Navy (2014a).

Authors' elaboration.

As shown above, Brazil has five active submarines - Tupi, Tamoio, Timbira, Tapajó, and Tikuna. Different contracts signed with the German consortium Ferrostaal/HDW in the 1980s ordered the construction of four IKL-209-1400 model submarines, being the first one built in the European country and the others in the Rio de Janeiro Navy Arsenal (AMRJ). In 1995, the construction of a fifth submarine was ordered, which would become the Tikuna, incorporating innovations designed by Brazilian engineers. The project covered the supply of material and training for specialized personnel from the Brazilian Navy, sent to accompany the construction at the German shipyard. In total, 70 professionals did internships during its construction (Galante and Martini, 2014).

Table 2 presents the number of submarines incorporated into navies around the globe, with the purpose of examining Brazil's capacity and relative power in terms of its Submarine Force. The numbers refer to information provided by the countries themselves and by different military database up to 2017 . 
TABLE 2

Number of submarines incorporated into the Armed Forces by country

\begin{tabular}{|c|c|c|c|}
\hline Country & Conventional & Nuclear-powered & Total \\
\hline North Korea & 76 & 0 & 76 \\
\hline United States & 0 & 72 & 72 \\
\hline China & 65 & 3 & 68 \\
\hline Russia & 30 & 33 & 63 \\
\hline Iran & 33 & 0 & 33 \\
\hline Japan & 17 & 0 & 17 \\
\hline India & 13 & 2 & 15 \\
\hline South Korea & 15 & 0 & 15 \\
\hline Turkey & 12 & 0 & 12 \\
\hline Greece & 11 & 0 & 11 \\
\hline United Kingdom & 0 & 11 & 11 \\
\hline France & 0 & 10 & 10 \\
\hline Pakistan & 8 & 0 & 8 \\
\hline Italy & 7 & 0 & 7 \\
\hline Algeria & 6 & 0 & 6 \\
\hline Israel & 6 & 0 & 6 \\
\hline Singapore & 6 & 0 & 6 \\
\hline Australia & 6 & 0 & 6 \\
\hline Peru & 6 & 0 & 6 \\
\hline Vietnam & 6 & 0 & 6 \\
\hline Germany & 6 & 0 & 6 \\
\hline Norway & 6 & 0 & 6 \\
\hline Sweden & 5 & 0 & 5 \\
\hline Poland & 5 & 0 & 5 \\
\hline Brazil & 5 & 0 & 5 \\
\hline Egypt & 5 & 0 & 5 \\
\hline Netherlands & 4 & 0 & 4 \\
\hline Colombia & 4 & 0 & 4 \\
\hline Chile & 4 & 0 & 4 \\
\hline Canada & 4 & 0 & 4 \\
\hline Azerbaijan & 4 & 0 & 4 \\
\hline Taiwan & 4 & 0 & 4 \\
\hline Indonesia & 4 & 0 & 4 \\
\hline South Africa & 3 & 0 & 3 \\
\hline Spain & 3 & 0 & 3 \\
\hline Argentina ${ }^{1}$ & 2 & 0 & 2 \\
\hline Ecuador & 2 & 0 & 2 \\
\hline Malaysia & 2 & 0 & 2 \\
\hline Portugal & 2 & 0 & 2 \\
\hline Venezuela & 2 & 0 & 2 \\
\hline
\end{tabular}

Sources: Nation Master (2014); GFP (2017); Fuerza... (2017).

Authors' elaboration.

Note: 'The conventional submarine ARA San Juan disappeared in November 2017 during a mission. The hypothesis considered is that there was an explosion on this vessel, causing the death of its crew. The table, therefore, no longer considers this submarine as part of Argentine fleet.

Obs.: 1. Some of the data contained in the table should not be considered absolute because they are the result of consultations with the different sources and databases cited. The fact is that not all countries officially disclose defense-related and military data because it is considered sensitive information. In any case, the table provides a general understanding of the distribution of the submarine forces around the globe. 
Even though the presentation of absolute numbers is relevant to better understand how each country stands on this issue, it is important to mention that a more detailed examination can be carried out in order to investigate the technologies employed in the submarines from each country. For example, the fact that North Korea has more submarines than the United States does not mean that the North Korean fleet is more efficient than that of the North-Americans. Considering the scope of this study, the option was taken to list only the number of conventional and nuclear-powered submarines that each nation has.

Taking into consideration the presented figures, in can be seen that Brazil is not yet in a position of prominence in the international scenario in terms of its Submarine Force. Brazil does not lead even in South America. Peru, whose submarine fleet began in 1911 , is considered a pioneer in the region and currently has six vessels of this type. From a BRICS perspective, ${ }^{25}$ Brazil is behind China (68), Russia (63), and India (15), having more submarines only when compared to South Africa (3). Furthermore, together with the latter, Brazil still does not have nuclear-powered submarines in its Force, unlike the first three.

Due to its large coastal region, its vast strategic environment, and the extent of the AJB, it is imperative for Brazil to give a priority to the maintenance and expansion of its submarine fleet in its defense-related public policies. The protection of abundant mineral resources located in its CS, as well as the strategic importance of sea denial, adds to the relevance of making investments in the Brazilian Navy Submarine Force. In this sense, it is important to discuss and evaluate the Submarine Development Program (PROSUB), which has as its main purpose to build four conventional submarines and the country's first nuclear-powered submarine, in addition to developing the facilities and technologies needed to do this.

\section{THE SUBMARINE DEVELOPMENT PROGRAM AND THE BRAZILIAN NUCLEAR-POWERED SUBMARINE}

Following the contracts signed in the 1980s and 1990s, the Brazilian Navy carried out negotiations with the German company ThyssenKrupp (which had bought HDW, part of the consortium responsible for the previous contracts) in the mid-2000s for

25. Group formed by Brazil, Russia, India, China, and South Africa. 
modernizing the Brazilian submarines and for the acquisition of an IKL-214 submarine, an evolution of Type 209 submarine in operation in Brazil. The adoption of the German model was due to the logistical convenience of continuing the support and maintenance of the submarines of the same origin, along with preserving a culture and the technologies already assimilated by Brazilian crews and engineers (Galante and Martini, 2014).

The discovery of oil of high commercial value in the pre-salt layer of the Brazilian continental shelf in 2007 brought the exploitation of the AJB to the center of political and economic discussions, as well as its protection in the face of external threats. The debate about the importance of Brazil building a nuclear-powered submarine as a vessel with strategic and dissuasive characteristics was therefore reignited. Considering that the German suppliers did not work with the technology required for manufacturing the hulls of nuclear-powered submarines, ${ }^{26}$ this made it necessary to look for new companies on the international market that would meet this objective. The contract with the German manufacturer, therefore, which had already been approved, was not signed.

After dialogues held at the presidential level, Brazil and France signed a strategic partnership in December 2008, in which the institution of PROSUB stands out among the projects enlisted. The choice for France was made in a context in which only five countries designed nuclear-powered submarines - United States, United Kingdom, Russia, and China, apart from France. ${ }^{27}$ The United Kingdom and the United States, however, do not produce conventional submarines, which would reduce the scope of the agreement to be signed. Being a large program that involves the transfer of technology, personnel training, and improvement of the infrastructure required for building submarines, the PROSUB also includes a program of nationalization of equipment and systems of high technological content, raising the level of science, technology, and innovation in the country and in Brazilian companies (Brazil, 2018e).

\subsection{PROSUB: execution and expected results}

In 2011, the Brazilian Ministry of Defense (MD) established a working group with the aim of developing actions for preparing the Defense Articulation and Equipment Plan

26. Due to their increased size and weight, nuclear-powered submarines need stronger hulls than conventional submarines, requiring a different and more advanced technology for their construction.

27. Currently, India operates nuclear-powered submarines of Russian origin and is also undergoing operational tests of the first model to be built in the country. 
(PAED, acronym in Portuguese) in order to substantiate the Armed Forces's strategic programs and meet the demands for new defense capabilities in the country (Brazil, 2011; 2012a). The PAED covers 35 projects from the Brazilian Navy, the Brazilian Army (EB, acronym in Portuguese), and the Brazilian Air Force (FAB, acronym in Portuguese), and seeks to further consolidate the acquisition and development of defense equipment and strengthen the teaching, research, and education in the sector (Andrade et al., 2016).

Presented with a long-term time horizon, the PAED will guarantee Brazil positive externalities in different fields - military, political, economic, scientific, technological, and social (Brazil, 2012a). One of the Brazilian Navy's priority projects contained in the PAED is the Development of the Navy's Core Capabilities, which is aimed to modernize and expand this Force's operational capability and includes the PROSUB. It should be also noted that the project encompasses different programs and actions, such as a surface vessel acquisition program (PROSUPER), a patrol vessel acquisition program, an aircraft carrier acquisition program (PRONAE), and an amphibious ship acquisition program (PRONANF) (Brazil, 2012a).

Appointed as a priority by the LBDN, as published in 2012, the Navy Nuclear Program (PNM, acronym in Portuguese) is executed since 1979 with the proposal of gaining expertise in the nuclear fuel cycle and building a nuclear power plant for generating electricity, which is the Nuclear-Electric Generation Laboratory (LABGENE, acronym in Portuguese) (Brazil, 2012a; 2018d). The PNM also foresees strengthening the Navy's Technological Center in Sáo Paulo (CTMSP) and building a prototype of the reactor that will serve as the basis for the country's first nuclear-powered submarine (Brazil, 2012a).

Intrinsically related, the PROSUB and the PNM are subordinated to the Directorate General for Nuclear and Technological Development of the Navy (DGDNTM), which also incorporated the CTMSP. Decree No. 8.900 of November 10 $10^{\text {th }}, 2016$ formalizes the amendment in the name given to the Secretariat of Science, Technology and Innovation of the Navy to DGDNTM, and the incorporation of PROSUB's and PNM's activities, consolidating the Brazilian Navy's ST\&I organizational structures.

Led by Admiral Bento Costa Lima Leite de Albuquerque Júnior, then directorgeneral of DGDNTM, the restructuring of this body included optimizing the allocation of resources and the execution of the Brazilian Navy's main current project- 
developing the nuclear-powered submarine. ${ }^{28}$ In this context, the DGDNTM is the central executive body of the Navy's Science \& Technology System, with the responsibility to coordinate the activities of research and development, as well as ST\&I (Brazil, 2017a).

In line with the first version of the END, published in 2008, the same year as the strategic partnership with France, PROSUB seeks to

ensure the objective of sea denial, for which Brazil shall count on an imposing naval submarine force composed of conventional and nuclear-powered submarines and shall maintain and develop its capacity to design and manufacture both conventional and nuclear-powered submarines, making investments and building the partnerships necessary for the success of this undertaking (Brazil, 2008, p. 21). ${ }^{29}$

The development of the nuclear-powered submarine is directly connected to the END also with regard to the three strategic and essential sectors for national defense: space, cybernetics, and nuclear. ${ }^{30}$ By reinforcing that the nuclear axis transcends the division between development and defense, the document affirms the importance of "complete nationalization and development, in industrial scale, of the fuel cycle (...) and of the technology for building reactors, for exclusive use of Brazil" (Brazil, 2017, p. 33). ${ }^{31}$

Due to the fact that the sensitive technologies developed in France were under control of the State, the PROSUB contracts needed to be preceded by documents signed between authorities of that country and Brazil. In this sense, in December 2008, documents and agreements of high strategic value were signed between the two countries, namely: $i$ ) action plan (strategic partnership) foreseeing cooperation in the area of defense, established by the respective presidents of the Republic; ii) cooperation agreement in the area of submarines signed by the Ministers of Defense; iii) technical adjustment concerning the design, construction, and commissioning of submarines signed by the Navy commanders; and iv) the program's main contract, related to the transfer of technology and provision of technical services (Moura Neto, 2012).

28. For more details, access: <https://goo.gl/BUzxDW>.

29. This excerpt from the text remained quite similar in the END version launched in 2012 (Brazil, 2012b, p. 71). The version submitted to the National Congress in 2017, which precedes the disclosure of a new edition of the document, mentions only "to ensure the task of sea denial, Brazil shall count on an imposing naval submarine force composed of nuclearpowered and conventional submarines" (Brazil, 2017, p. 27).

30. Under the responsibility of Brazilian Air Force, Army and Navy, respectively.

31. The excerpt presented in the first version of the END in 2008 was fully maintained in the 2012 edition, as well as in the version submitted to the National Congress in 2017. 
The PROSUB comprises a total of eight commercial contracts that oversee the development of three major undertakings: $i$ ) the design and construction of a Shipyard and Naval Base (EBN, acronym in Portuguese) and a Manufacturing Unit of Metallic Structures (UFEM, acronym in Portuguese); ii) the construction of four conventional submarines (S-BR), taking as a model the French Scorpene class and the detailed project of its intermediate section, modified to meet the Brazilian Navy's requirements; and iii) the design and construction of the hull of the first SN-BR. The contracts also deal with the issue of offset ${ }^{32}$ and the acquisition of torpedoes and torpedo decoys (Brazil, 2014c).

Among the various companies participating in PROSUB, the following stand out: the French company Naval Group (former DCNS) ${ }^{33}$, responsible for the project's technology transfer, which does not include nuclear technology, and for providing specialized technical services and information; the construction contractor Norberto Odebrecht (CNO), a Brazilian company chosen by the Naval Group to act as a national partner in the program; and the Nuclebrás Heavy Equipment (NUCLEP, acronym in Portuguese), linked to the Ministry of Science, Technology, Innovation, and Communications (MCTIC) and in charge of the heavy mechanical and industrial activities. Together, the Naval Group and $\mathrm{CNO}$ constituted the joint venture Itaguaí Naval Construction (ICN, acronym in Portuguese) $)^{34}$ and the Baía de Sepetiba Consortium (Brazil, 2018f).

With regard to the Naval Group's performance within PROSUB, the company has provided hundreds of employees working on the program, totaling nearly 3 million working hours in the first five years of this partnership. Various industrial centers in France are part of the cooperation efforts, such as Lorient for the project, Cherbourg for production, Lane for the development of strategic equipment, Nantes-Indret for the propulsion, and Toulon for the combat system. The first S-BR (Riachuelo) had two of its four sections built in the shipyard of the French company located in Cherbourg, as a form of exercising and training Brazilian technicians and engineers (Naval Group, 2015; Groizeleau, 2010).

32. The offset concept comes from the economic sciences and consists of a counteroffer in a particular contract or agreement. In this context, offsets are compensations that in general involve the supply of high-value products and/or of high technological sophistication and may include the transfer of technology and knowledge, as well as investments made and facilitation of access to a specific market (UNCITRAL, 1993).

33. DCNS is the acronym for Direction des Constructions Navales Services. The company's name was changed to Naval Group in 2017.

34. Through Emgepron (Empresa Gerencial de Projetos Navais), the Brazilian Navy holds a golden share of ICN, which gives it veto power in decisions and negotiations. 
The Naval Group also inaugurated in 2009 a school of submarine design in Lorient, with the aim of training the Brazilian technicians to design the non-nuclear part (hull and structure) of the SN-BR. The first class that returned to the country after an 18-month course was composed of about 30 military engineers from the Brazilian Navy and represented an important step for the technology transfer process provided in the bilateral agreement. The French group also has the task of collaborating with Brazil in managing the project and building the EBN in Itaguaí-RJ (Groizeleau, 2010).

The construction of the EBN, under mandate from the $\mathrm{CNO}$ and carried out with the technical supervision of the Naval Group, started in 2010 with its expected completion in 2021. The project includes two shipyards for building and maintaining the submarines, a naval base, a specialized maintenance center, a ship lift platform, and an administrative area for the program. The EBN inaugurated the main building of the shipyard in 2014 and carried out the commissioning of the shiplift in late 2017 (Brazil, 2014; 2017). The UFEM, in turn, was inaugurated in 2013, having been built in the brief period of two years (Brazil, 2018a).

Considered one of the objectives of the PROSUB, the construction of four S-BR will take a model based on the French Scorpène class submarine, but will have significant technical changes according to specifications established by the Brazilian Navy. ${ }^{35}$ According to the initial planning, the first S-BR should have been launched in 2016, but this schedule was readjusted due to budget issues. Therefore, the launching of the Riachuelo (S-40) took place in December $2018^{36}$ while the others - Humaitá (S-41), Tonelero (S-42), and Angostura (S-43) - are expected to be launched in 2020, 2021, and 2022, respectively (Brazil, 2018f).

In January 2018, the Brazilian Navy and the ICN transferred three joined sections of the submarine Riachuelo, a logistical operation that demanded detailed planning for months and included removing sections of the electricity grid and occasional interruptions in vehicle traffic. A mobile platform with 320 wheels was responsible for transporting the approximately 600 tons of the three sections along the $5-\mathrm{km}$ distance, traveling a total of eleven hours in a transfer maneuver of a significant importance to the project (Brazil, 2018d).

35. In particular, it was requested the addition of a section to the submarine hull, which increases its length and weight, with the purpose of expanding the navigation time, extending its autonomy and allowing a longer period of patrolling. 36. This information was updated for this version of the text, considering that the launching occurred after the publication of the original paper. 
The development of the first Brazilian nuclear-powered submarine, which has been on the government's agenda for discussion since the 1970s, can be regarded as the ultimate objective of the PROSUB and one of the main goals of the PNM. Named "Alvaro Alberto" (SN-10), ${ }^{37}$ the submarine will provide for Brazil not only strategic functions of sea denial and surveillance of maritime borders, but also a process of technological spillover and an intense nationalization of advanced components and mechanical, electronic, and industrial systems.

\subsection{The Brazilian Navy and nuclear research: a history of the Navy Nuclear Program}

In order to understand the Brazilian nuclear-powered submarine project, it is necessary to understand the historical context of nuclear research in the country and the participation of the Brazilian Navy in nuclear development. Still dependent on the supply of enriched uranium from the United States up until the 1970s, Brazil began to seek nuclear autonomy so as to achieve independence in the supply of its research and energy reactors. Because of this, the Brazilian government signed in 1975 an agreement with the Federal Republic of Germany (West Germany) (Andrade et al., 2016). ${ }^{38}$

The signing of the agreement resulted in the creation of Empresas Nucleares Brasileiras S.A. (Nuclebrás) in 1974 and provided for the construction of eight reactors and the installation of nuclear energy companies and factories of heavy equipment plants in Brazil. Germany would also transfer the technology of uranium enrichment by using a jet-centrifugation process. Thus, the beginning of the Brazilian Nuclear Program (PNB, acronym in Portuguese) was announced in 1977. However, constant pressure from the United States prevented the transfer of sensitive technology needed, in particular in relation to the nuclear fuel cycle. Such limitations resulted in the Brazilian decision to independently make the efforts necessary for gaining expertise and domain in the nuclear area (Lana, 2014).

The first idea of building a nuclear-powered submarine in Brazil officially emerged during the negotiations for cooperation with Germany. In the midst of the bilateral talks,

37. In honor of Álvaro Alberto da Mota e Silva (1889-1976), Vice Admiral of the Brazilian Navy, scientist, and one of the main responsible for implementing the Brazilian Nuclear Program (PNB).

38. The search for autonomy occurred in the context of the first oil crisis in 1973, when the United States suspended new contracts for supplying enriched uranium due to an increase in internal demand for nuclear energy (Lana, 2014). 
the Germans proposed in 1976 to include nuclear propulsion in the agreement, without considering, however, the construction of a specific hull for this submarine. Due to the changes and restrictions in the terms of business, Brazil realized that it was necessary to develop its own nuclear technology. Therefore, in 1978 the Brazilian Navy stated that it was essential to build submarines of this type, but indicated that it would be necessary to first gain an understanding of the nuclear fuel cycle to only then develop an indigenous system of nuclear propulsion, using exclusively national efforts (Lana, 2014).

With the purpose of achieving a greater understanding of the nuclear fuel cycle, ${ }^{39}$ the nuclear program developed by Brazil was initially composed of three spheres of research in an attempt to build a national reactor: i) the Brazilian Army was investigating the possibility of a graphite-moderated reactor; ii) the Brazilian Air Force explored laser-based uranium enrichment; and iii) the Brazilian Navy invested in ultracentrifugation as a way to enrich the material. The latter became the method that proved to be more viable for producing nuclear fuel, so the Navy Nuclear Program (PNM) was launched in 1979 (Lana, 2014; Andrade et al., 2016).

Coordinated by the Navy's Technological Center in São Paulo (CTMSP), the PNM is developed mainly at the Aramar Nuclear Industrial Center (CINA, acronym in Portuguese), intalled in 1985. With the objective of establishing the indigenous technical competence needed to design, build, commission, operate, and maintain a Pressurized Water Reactor (PWR) and to produce nuclear fuel, the PNM seeks to build a nuclear power plant in addition to achieving complete control of the nuclear fuel cycle, as already pointed out (Brazil, 2007; Lana, 2014; ADESG, 2018).

In September 1987, Brazil announced the domain of uranium enrichment technology by ultracentrifugation, representing an important step in terms of nuclear research. Currently, the country has reached a full technological understanding of all the stages of the nuclear fuel cycle (Lana, 2014; CNEN, 2016b). With regard to the other PNM front - the installation of a nuclear power plant - the Brazilian Navy is building the Nuclear-Electric Generation Laboratory (LABGENE, acronym in

39. The nuclear fuel cycle is the set of industrial stages that the uranium undergoes since its mining all the way until the controlled release of nuclear energy is started. These stages include milling, conversion, enrichment, reconversion, and the manufacturing of the fuel element. 
Portuguese) at CINA. It is a nuclear plant with a reactor approximately 10 meters tall, being a prototype on land of the SN-BR nuclear propulsion system (Lana, 2014).

Created in 2008, the General Coordination of the Nuclear-Powered Submarine Development Program (COGESN, acronym in Portuguese) is responsible for managing the development, nationalization, and construction activities developed under the PROSUB, being the managing body of all its commercial contracts. The COGESN is an organization subordinate to DGDNTM, which also incorporated the CTMSP and PNM, as previously mentioned. ${ }^{40}$ In a 2017 interview, the then DGDNTM's director general pointed out that the Brazilian Navy is the only navy in the world whose nuclear program is under the safeguards of the International Atomic Energy Agency (IAEA), being also under the Brazilian-Argentine Agency for Accounting and Control of Nuclear Materials (ABACC, acronym in Portuguese) (Albuquerque Júnior, 2017a).

\subsection{The Brazilian nuclear-powered submarine "Álvaro Alberto"}

As presented throughout this paper, the advantages of a nuclear-powered submarine in comparison to conventional (diesel-electric propulsion) are various: virtually unlimited autonomy, meaning that no surfacing is necessary to charge batteries; navigation over longer distances at a higher speed and during unrestricted time, allowing the monitoring or the escorting of surface vessels and the chasing of vessels of interest; its extremely robust structure, resulting in a greater resistance to high pressures and therefore a greater depth of immersion to be reached without compromising its operation. However, the main negative aspect of these submarines, besides the high cost, is the intense and constant noise radiated in the water as it travels, as certain propulsion, cooling, and monitoring equipment cannot be turned off as in conventional submarines.

With respect to the differences between the nuclear-powered and conventional submarines, it is vital to understand that both have advantages and disadvantages, as already raised earlier. The construction of a nuclear-powered submarine by Brazil, though it requires considerable investments and efforts, will provide the Brazilian Navy with the initiative of action in the South Atlantic. While the conventional submarine

40. For more information, access: <https://goo.gl/z9Frp3>. 
in general acts at focal points, waiting for possible targets to pass by it, the nuclearpowered submarine, due to its greater speed and consequent freedom of movements, can reach its targets of interest and choose the best moment to attack (Galante, 2017).

Even though countries such as the United States and the United Kingdom have abandoned the construction and operation of conventional submarines, the employment of both types shows to be strategic for naval forces, especially in relation to coastal zones. The diesel-electric propulsion model works best in shallow waters, which is important for naval operations along the Brazilian coastline. The use of conventional and nuclear-powered submarines are therefore complementary, since the first use the strategy of position and the latter the strategy of movement (Galante, 2017).

The development of the Brazilian nuclear-powered submarine is divided into four main stages: design and feasibility studies, preliminary project, detailed project, and construction. The project began in July 2012 with the first stage ending in August 2013. The second stage consisted of preparing the preliminary project and was completed in January 2017, providing the necessary conditions to prepare the details, which was expected to commence between 2018 and 2019. The construction of the submarine is expected to begin in 2020 and should be finalized by 2029, which is when the "Álvaro Alberto" will undergo tests and examinations at the pier and at sea before being transferred to the operating sector of the Brazilian Navy (Brazil, 2018h).

In 2013, the PROSUB together with the PNM were included in the federal government's Growth Acceleration Program (PAC, acronym in Portuguese), confirming its great strategic importance for Brazil. Budget cuts were made in 2015 and 2016, hindering the progress of the project, especially regarding the construction of the EBN (Drummond, 2017). The insertion of the PROSUB in the PAC can be explained due to the many benefits that the program brings to the State and to the Brazilian society. Structured on the pillars of technology transfer, nationalization, and training of personnel, the project is deeply connected to science, technology, and innovation (ST\&I), ensuring in all of its stages considerable returns and positive externalities to society (Brazil, 2014a).

\subsection{Science, Technology, \& Innovation: technological spillover and social- environmental externalities of the SN-BR "Álvaro Alberto" project}

The technology transfer and nationalization processes related to the execution of PROSUB generate conditions for a significant technological spillover in Brazil, that is, for the 
dissemination of knowledge across different production chains, both civil and military. The dual use of technologies, a common element when it comes to the defense industry, contributes to the development of ST\&I and to the national industry. Within the PROSUB context, this technological spillover is directly connected to the nationalization of equipment and systems and to huge research efforts in partnership with universities, research institutes, and private and state companies (Brazil, 2014a). The technological spillover concept is deeply related to innovation and the overflow effect of a military technology into different civil sectors. Thus, the defense industry in general is an important agent for generating and developing ST\&I, especially encouraging other technological and industrial areas. In this sense, technological knowledge is considered an element of influence and domination in the international scenario, increasing a country's power of deterrence (Schmidt, 2011; Andrade and Leite, 2017).

In his in-depth study on the Defense Advanced Research Projects Agency (DARPA), which is subordinate to the United States Department of Defense and responsible for financing and developing new technologies for military use, Mansueto Facundo de Almeida Júnior highlights that "the effort of innovation [employed by the agency], in general, translates into several products for commercial use" (Almeida Júnior, 2013, p. 28, translated by the authors). The author also points out the crucial importance of encouraging innovation offered by the North-American government, as well as building research networks with universities, private companies, and research centers. Even if Brazil does not have a central body that coordinates the scientific and technological projects in the area of defense, it is necessary to consider these elements when developing strategic programs within each branch of the Armed Forces.

The scientific-technological development arising from PROSUB, therefore, represents a constitutive part of Brazil's strategic interest, also meaning high-level technical qualification, generation of qualified jobs, and stimulus to the local and national economy, as shown by the aspects presented below.

It is important to point out that the PROSUB represents some of the largest contracts ever signed by Brazil, as well as the most extensive industrial and technological training program in the history of the Brazilian defense industry (Drummond, 2017). The focus on the nationalization of the components purchased and developed for the EBN and for the submarines occurs in all phases of the program, since the construction of the UFEM, which has a nationalization index of approximately $95 \%$, all the way 
to the maintenance of the SN-BR. In this regard, more than 700 Brazilian companies have already been invited to participate in the program as suppliers (Brazil, 2014c). ${ }^{41}$

In a spectrum related to the defense industry, the PROSUB provides incentives to the following areas: electronics, naval engineering, heavy mechanics, computing (development of hardware and software), precision mechanics, optronics, mechatronics, electromechanics, metallurgy, chemistry, and nuclear. The program also promotes benefits to the Brazilian shipbuilding industry and to the national off-shore oil prospecting platforms sector (Drummond, 2017).

It is also interesting to point out that some of the main Brazilian companies in the defense area that currently operate in the market are those that have benefited from major military projects from the $1980 \mathrm{~s},{ }^{42}$ during the period when the national Defense Industrial Base (DIB) reached its peak (Andrade, 2016). Considering this, the PROSUB's broad dimension and scope also suggests that the companies participating in the program will enjoy remarkable positive effects especially resulting from the nationalization component, ensuring the development and expansion of their business in the medium and long term.

Advances in Brazilian foreign trade can also be credited to PROSUB and PNM. In 2016, for example, Brazil began to export enriched uranium to Argentina through the company Induistrias Nucleares do Brasil (INB) and with technology from the Brazilian Navy. Thus, the country, that used to sell only the crude ore, becomes an important player in the market of nuclear fuels, being able to provide a high value-added product to other countries, with the advantage of being the only country in Latin America that dominates the technology required for its production (Lana, 2014; Drummond, 2017).

According to Rear Admiral André Luís Ferreira Marques, the then Navy's Nuclear Development Director, this export changes the tier of the country, which ceases to be seen only as an ore reservoir, acquiring the recognition of having the necessary capabilities and expertise to sell nuclear fuel in the international market (Marques, 2017). Furthermore, once trained and qualified, Brazil will also be able to export

41. On May 29th, 2018, the General Coordination of the Nuclear-Powered Submarine Development Program (COGESN, acronym in Portuguese) held an institutional presentation during a technical visit by Ipea researchers.

42. Some examples are the production and export of armored vehicles by Engenheiros Especializados S/A (Engesa) and aircraft by Empresa Brasileira de Aeronáutica (Embraer). 
submarine equipment and systems and even the vessels themselves, which will represent a large step in strengthening the country's Defense Industrial Base (DIB) (Lana, 2014; Drummond, 2017).

In addition to the relevance of the PROSUB for Brazilian national defense and the development of the DIB, the program shall also contribute to different sectors in the country. The highly advanced industrial and nuclear technology developed in the project will allow important advances in the areas of nuclear medicine, agriculture, environment, and the chemical industry. These applications will occur, in particular, within the context of Brazilian Multipurpose Reactor (RMB, acronym in Portuguese). ${ }^{43}$

The RMB has the main objectives of producing radioisotopes and radiopharmaceuticals to be used in various areas, the irradiation and testing of nuclear fuels and structural materials in order to assess their integrity when subjected to high doses of radiation, and the development of scientific and technological research using neutron beams. ${ }^{44}$ The reactor shall have multiple purposes such as the supply of radioisotopes for application in nuclear medicine, industry, environment and other sectors. The training of the national industry in testing and qualification of nuclear materials and fuels should also be highlighted as a fundamental step to ensure safety in the development of this technological cycle while manufacturing these products (CNEN, 2016a).

The execution of the entire RMB project is under the responsibility of the National Nuclear Energy Commission on Nuclear Energy (CNEN, acronym in Portuguese) and counts with the support of Finep, a national funding agency for studies and projects, which signed an agreement of R $\$ 150$ million - in total, it is estimated the absortion of approximately US\$ 500 million (R\$1.87 billion). ${ }^{45}$ Amazônia Azul Tecnologias de Defesa S.A. (Amazul), a Brazilian state company that supports the PROSUB's development, is the co-executer of the RMB detailed project. Invap S.E., an Argentine public technology company, also participates in the implementation of this project. The venture will be built

43. For more information, access: <https://goo.gl/L62iLR>.

44. For more information on the subject, access the Nuclear and Energy Research Institute (IPEN, acronym in Portuguese) website: <https://goo.gl//Kb9DQE $>$.

45. The exchange rate values were those of July $31^{\text {st }}, 2018$. 
on a plot of land of approximately 2 million $\mathrm{m}^{2}$ located in Iperó (SP), next to CINA. Its operation, however, will be carried out by CNEN. ${ }^{46}$

In the area of medicine, the development of the RMB will make Brazil selfsufficient in the production of radioisotopes, elements used in the manufacture of radiopharmaceuticals that serve for diagnosing and treating diseases such as cancer. Currently, Brazil imports each year approximately $\mathrm{R} \$ 48$ million of these inputs from Argentina, Russia, and South Africa, sending them to more than 400 hospitals and clinics in the country. ${ }^{47}$

According to the then Brazilian Navy's General Director of Nuclear and Technological Development, the per capita use of nuclear medicine procedures in Brazil (totaling approximately R $\$ 2$ million annually) is two times lower than in Argentina and six times lower than in the United States. There is also a repressed demand in the sector, and the RMB will be able to meet it and even expand the amount of radiopharmaceuticals offered to society (Albuquerque Júnior, 2017b).

In the sectors of agriculture, industry, and the environment, the RMB's application will be to develop technologies that enable the use of radioactive tracers, ${ }^{48}$ the testing of materials such as inertial sensors of oil platforms, the location of cracks in surfaces such as aircraft wings, and the verification of the amount of pesticides contained in food (Drummond, 2017). ${ }^{49}$

As part of the construction of the S-BR, the SN-BR, and the Shipyard and Naval Base (EBN, acronym in Portuguese), a personnel recruitment and selection center has been set up with the aim of generating job opportunities for the population living in Itaguaí-RJ. Approximately 22,000 direct jobs and 40,000 indirect jobs should be generated during the development of PROSUB (Brazil, 2018i). In this sense, the social program Acreditar ("Believe", in Portuguese), created within the scope of PROSUB, aims to train people in areas of civil and naval construction, among other specialties,

46. For more information, access: <https://goo.gl/L62iLR $>$ and $<$ https://goo.gl/Kb9DQE $>$.

47. More details at: $<$ https://goo.gl/L62iLR>.

48. Radioactive tracers are substances marked with one or more radioactive atoms, making them easy to detect and measure, being therefore able to be monitored by radiation detectors. They are mostly used in scientific research and in some industrial, chemical, and medical segments.

49. For more information, access: <https://goo.gl/L62iLR>. 
and their subsequent hiring, with the goal of training 2,000 people until the delivery of EBN (Brazil, 2014b; 2018e).

It is therefore clear that the technological spillover resulting from the PROSUB technology transfer and the advances in studies on nuclear technology carried out for the RMB will bring several benefits to Brazil and to Brazilian society, not only in the areas related to national defense, but also in different civil sectors, as pointed out throughout this section. Furthermore, the PROSUB includes in its scope a series of measures aimed to social-environmental responsibility and contributes to the development of the region, resulting in various positive externalities (Brazil, 2014a).

The PROSUB also includes initiatives concerning environmental management and compensation. For the construction of the EBN, for example, it was necessary to do a dredging of the entire coastal area, which has contributed to the decontamination of the region (that previously housed a chemical industry), and to recover the aquatic biota and the local fauna. Furthermore, a compensatory planting of more than $195,000 \mathrm{~m}^{2}$ of several Atlantic Forest species was carried out in order to reduce the project's environmental impacts (Brazil, 2014a).

It can be perceived, from the externalities and actions pointed out, that the PROSUB represents a program with a range of positive results in different areas. In addition to its main objective, which ultimately consists of building Brazil's first nuclear-powered submarine, the development of the program will provide important progress in ST\&I, reflecting advances in the Brazilian production and industrial cycles while bringing benefits to the country's entire society. The PROSUB means, above all, a large increase in Brazil's deterrence and naval power. In addition to gains in national defense, the development of the program also means the expertise and domain of the advanced technologies and the training of extremely qualified people specialized in different fields of industrial and technological knowledge.

\section{CONCLUSION}

The vastness and wealth of the Blue Amazon, combined with the risks and threats present in its strategic environment, as well as the high volume of national foreign trade that crosses vulnerable regions of the South Atlantic, make it imperative for Brazil to protect its legitimate interests at sea. To do so, it is necessary to maintain 
its Navy provided with adequate platforms and equipment, in order to carry out its constitutional mission of defending and protecting the resources contained in the AJB and inland waters.

In this context, naval power is essential for Brazil, and the preparation of this power becomes an essential element of naval strategy and should ideally take place during periods of peace. A naval force in particular - that of submarines - plays an important role in the tasks of sea denial and limited control of maritime area, with the Brazilian nuclear-powered submarine being a fundamental component for the country to obtain and maintain a dissuasive naval power.

The analysis presented in this paper demonstrates that the development of the SN-BR under the PROSUB context meets at least two key objectives. The first one, which is more prominent and noticeable, is to increase the Brazilian Navy's operational capacity and thereby enhance its ability to deter vested interests and to protect national waters, as well as enable an effective presence in the South Atlantic. The second one, which is more implicit, is the technological spillovers provided by the development and improvement of technologies embedded in the submarine, raising the level of science, technology and innovation (ST\&I) in the country. It should also be emphasized that, among all the national defense's strategic programs, this one is considered to be of the highest level in the industrial and technological areas.

Thus, the need to maintain and enhance PROSUB becomes evident, despite the fiscal adjustment context faced by Brazil. Although the importance of controlling public spending, it must be ensured that any budgetary adjustments promoted within the federal government shall not cause the stagnation of this program. It should be noted that budgetary constraints related to the PROSUB would ultimately affect the country's industrial and scientific-technological advance.

It is clear, therefore, that the PROSUB and the development of the Brazilian nuclear-powered submarine should be considered strategic and of high relevance to the country. Their immediate need in the aspects of Brazil's defense and their positive externalities, such as the technological spillover arising from the development of nuclear technology, the transfer of technology and the nationalization of components, support the justifications for the investments. 
Based on this understanding, this paper's central objective as presented in the introduction is fulfilled. The development of the nuclear-powered submarine, as well as conventional submarines, proves to be an important and suitable action for the strengthening of Brazilian naval power, for the purpose of national defense, for the promotion of the country in the international scenario, and for the development of the scientific, technological, and industrial base, generating significant benefits for the Brazilian society and contributing directly to ensure the sovereignty of Brazil.

\section{REFERENCES}

ABDENUR, A. E.; SOUZA NETO, D. M. O Atlântico Sul e a cooperação em defesa entre o Brasil e a África. In: NASSER, R. M.; MORAES, R. F. (Eds.). O Brasil e a segurança no seu entorno estratégico: América do Sul e Atlântico Sul. Brasília: Ipea, 2014. p. 215-238.

ALBUQUerQUe JUNIOR, B. C. L. Em defesa do país. Carta Capital, v. 974, Oct. 18, 2017a.

Poucos países têm as tecnologias do Brasil, diz almirante sobre programa nuclear.

Folha de Sáo Paulo, São Paulo, Nov. 7, 2017b. Retrieved Dec. 17, 2018, from: <https://goo. $\mathrm{gl} / \mathrm{WZt}$ tsk $>$.

ALMEIDA JÚNIOR, M. A política de inovação e a política de defesa: o caso da agência de inovação DARPA nos Estados Unidos. Radar: tecnologia, produção e comércio exterior, Brasília, n. 24, p. 27-35, 2013. Retrieved Dec. 17, 2018, from: <https://goo.gl/zmKfzY>.

ANDRADE, I. O.; CARPES, M. M.; LEITE, A. W. O desenvolvimento nuclear no Brasil e na Índia: uma comparação dos programas nacionais desses países. Revista da Escola de Guerra Naval, Rio de Janeiro, v. 23, n. 3, 2018. Retrieved Dec. 17, 2018, from: <https://goo.gl/uNoLM6>.

ANDRADE, I. O.; LEITE A. W. A indústria de defesa no contexto da política de inovaçáo. In: TURCHI, L. M.; MORAIS, J. M. Políticas de apoio à inovaçáo tecnológica do Brasil: avanços recentes, limitaçóes e propostas de açóes. Brasília: Ipea, 2017. p. 371-394.

ANDRADE, I. O. et al. O fortalecimento da indústria de defesa do Brasil. Rio de Janeiro: Ipea, 2016.

ANDRADE, I. O. et al. O Brasil na Antártica: a importância científica e geopolítica do Proantar no Entorno Estratégico Brasileiro. Brasília: Ipea, 2018.

ANDRADE, I. O. Base Industrial de Defesa (BID): contextualização histórica, conjuntura atual e perspectivas futuras. In: IPEA - INSTITUTO DE PESQUISA ECONÔMICA APLICADA. Mapeamento da Base Industrial de Defesa. Brasília: Ipea, 2016. p. 11-29. 
ARRUDA, R. G. Amazônia Azul: um patrimônio a ser defendido. 2014. Monografia (Especialização) - Departamento de Estudos, Escola Superior de Guerra, Rio de Janeiro, 2014.

ADESG - ASSOCIAÇÃO DOS DIPLOMADOS DA ESCOLA SUPERIOR DE GUERRA. Programa nuclear da Marinha. Rio de Janeiro: ADESG, 2018. Retrieved Dec. 17, 2018, from: <https://goo.gl/RVmDR4>.

BRAZIL. Decreto no 18.365, de 22 de agosto de 1928. Substitui as denominaçôes da Flotilha de Submersíveis e da Escola de Submersíveis e Armas Submarinas, por 'Flotilha de Submarinos' e 'Escola de Submarinos’. Diário Oficial, Brasília, p. 19633, Aug. 25, 1928. Seção 1. Retrieved Dec. 17, 2018, from: <https://goo.gl/6YLgwG>.

Decreto no 52.739, de 23 de outubro de 1963. Altera o regulamento para a base almirante Castro e Silva. Diário Oficial, Brasília, p. 8974, Oct. 24, 1963. Seção 1. Retrieved Dec. 17, 2018, from: <https://goo.gl/ojkSAi>.

Lei no 8.617 , de 4 de janeiro de 1993. Dispóe sobre o mar territorial, a zona contígua, a zona econômica exclusiva e a plataforma continental brasileiros, e dá outras providências. Diário Oficial, Brasília, p. 57, Jan. 5, 1993. Retrieved Dec. 17, 2018, from: <https://bit. ly/2SbDPaH>.

Decreto n⿳o 1.530 , de 22 de junho de 1995. Declara a entrada em vigor da Convenção das Naçóes Unidas sobre Direito do Mar, concluída em Montego Bay, Jamaica, em 10 de dezembro de 1982. Diário Oficial, Brasília, p. 9199, June 23, 1995. Seção 1. Retrieved Dec. 17, 2018, from: <https://bit.ly/2XHTch2>.

Marinha do Brasil. O Programa Nuclear da Marinha: apresentação do comandante da Marinha para a Comissão de Minas e Energia, Comissão de Ciência, Tecnologia, Comunicação e Informática e Comissão de Relações Exteriores e de Defesa Nacional da Câmara dos Deputados. [s.1.]: MB, 2007. Retrieved Dec. 17, 2018, from: <https://goo.gl/buCFJz>.

Ministério da Defesa. Estratégia Nacional de Defesa. 2. ed. Brasília: MD, 2008. Retrieved Dec. 17, 2018, from: <https://goo.gl/q3Ncnf>.

Ministério da Defesa. Portaria Normativa no 3.962, de 20 de dezembro de 2011. Aprova a metodologia do Sistema de Planejamento Estratégico do Ministério da Defesa (SISPED). Diário Oficial, Brasília, n. 244, p. 23, Dec. 21, 2011. Seção 1. Retrieved Dec. 17, 2018, from: <https://bit.ly/2LhVIEl>.

Ministério da Defesa. Livro Branco de Defesa Nacional. Brasília: MD, 2012a. Retrieved Dec. 17, 2018, from: <https://bit.ly/2XZhUJs>.

. Ministério da Defesa. Política Nacional de Defesa: estratégia nacional de defesa. Brasília: MD, 2012b. Retrieved Dec. 17, 2018, from: <https://goo.gl/5ctQn7>.

. Governo inaugura estaleiro na Base Naval da Marinha em Itaguaí (RJ). Governo do Brasil, Dec. 12, 2014a. Retieved Dec. 17, 2018, from: <https:/goo.gl/EogCQy>.

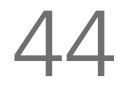


Marinha do Brasil. Cem anos da força de submarinos do Brasil. Rio de Janeiro: MB; FGV Projetos, 2014b. Retrieved Dec. 17, 2018, from: <https://goo.gl/Z4MQxt>.

. Marinha do Brasil. Programa de Desenvolvimento de Submarinos (PROSUB). [s.l.]: MB, 2014c. Retrieved Dec. 17, 2018, from: <https://goo.gl/cmVgW6>.

. Ministério de Minas e Energia. Boletim de exploraçáo e produção de petróleo e gás natural. 49. ed. Brasília: MME, 2016.

- Marinha do Brasil. Estratégia de ciência, tecnologia e inovaçáo da Marinha do Brasil. Brasília: MB, 2017a. Retrieved Dec. 17, 2018, from: <https://goo.gl/asA5HF>.

Ministério da Defesa. Estratégia Nacional de Defesa. Brasília: MD, 2017b. Retrieved Dec. 17, 2018, from: <https://bit.ly/2GcVxG9>.

. Ministério da Defesa. PROSUB realiza comissionamento do Shiplift. [s.l.]: MD, 2017c. Retrieved Dec. 17, 2018, from: <https://bit.ly/2XCXXsm>.

Marinha do Brasil. Centro de Instrução e Adestramento Almirante Áttila Monteiro Aché. Histórico. [s.l.]: MB, 2018a. Retrieved Dec. 17, 2018, from: <https://bit.ly/2LRNFO6>.

Ministério da Defesa. Marinha do Brasil. Centro Tecnológico da Marinha em São Paulo. Programa Nuclear da Marinha. [s.l.]: MD, 2018b. Retrieved Dec. 17, 2018, from: $<$ https://goo.gl/kwh8Fb>.

Clipe da transferência das seçóes do Submarino Riachuelo. YouTube, Jan. 17, 2018c. Retrieved Dec. 17, 2018, from: <https://goo.gl/f8CmKu>.

. Ministério da Defesa. Marinha do Brasil. MB e ICN realizam transferência das Seçóes do Submarino 'Riachuelo'. [s.1]: MB, 2018d. Retrieved Dec. 17, 2018, from: <https:// goo.gl/xuSfVQ>.

. Ministério da Defesa. Programa de Desenvolvimento de Submarinos. Finalidade. [s.l.]: MB, 2018e. Retrieved Dec. 17, 2018, from: <https://goo.gl/gtmiwH>.

. Ministério da Defesa. Programa de Desenvolvimento de Submarinos. Perguntas frequentes. [s.l.]: MB, 2018f. Retrieved Dec. 17, 2018, from: <https://goo.gl/qtVnWr>.

Ministério da Defesa. Programa de Desenvolvimento de Submarinos. Projeto e construçáo: submarino com propulsão nuclear. [s.l.]: MB, 2018g. Retrieved Dec. 17, 2018, from: <https://goo.gl/o6t6uU>.

Ministério da Defesa. Programa de DesenvolvimentodeSubmarinos. Responsabilidade social. [s.1.]: MB, 2018h. Retrieved Dec. 17, 2018, from: <https://goo.gl/YyEhxT>.

Ministério da Defesa. Programa de Desenvolvimento de Submarinos. UFEM. [s.l.]: MB, 2018i. Retrieved Dec. 17, 2018, from: <https://bit.ly/2BVH9QS>. 
Ministério da Defesa. Programa de Desenvolvimento de Submarinos. UFEM -

Primeiro passo rumo ao futuro. Brasília: MD, [s.d.]. Retrieved Dec. 17, 2018, from: <https:// goo.gl/rfSM4C>.

CNEN - COMISSÃO NACIONAL DE ENERGIA NUCLEAR. Com reator multipropósito, Brasil terá autonomia na produção de radioisótopos. CNEN, Aug. 19, 2016a. Retrieved Dec. 17, 2018, from: <https://goo.gl/ozNjXa>.

. Programa Política Nuclear: PPA 2016-2019 e LOA 2016. [s.l.]: CNEN, 2016b. Retrieved Dec. 17, 2018, from: <https:/goo.gl/Dc11no>.

DRUMMOND, C. A Marinha mostra o rumo. Carta Capital, São Paulo, v. 974, Oct. 18, 2017.

FARIA, E. P. O poder naval brasileiro e os interesses do país no Atlântico Sul. In: ACIOLY, L.; MORAES, R. F. Prospectiva, estratégias e cenários globais: visões de Atlântico Sul, África Lusófona, América do Sul e Amazônia. Brasília: Ipea. 2011. p. 83-116.

FERREIRA, E. B. L. Palavras do comandante da Marinha. In: SEMINÁRIO NOSSO MAR: PERSPECTIVAS BRASILEIRAS SOBRE O ATLÂNTICO SUL. Brasília: Clube Naval de Brasília, 2017. Retrieved Dec. 17, 2018, from: <https:/goo.gl/wZnmW9>.

FUERZA submarina de Colombia celebró en Cartagena sus 42 años de servicio. O Caracol Radio, 2017. Retrieved Dec. 17, 2018, from: <https://goo.gl/4JnFCE>.

GALANTE, A. Submarinos convencionais e nucleares de ataque. Poder Naval, 2013. Retrieved Dec. 17, 2018, from: <https://goo.gl/c3Egjq>.

O que não foi dito sobre o submarino desaparecido ARA San Juan. GGN, Nov. 27, 2017. Retrieved Dec. 17, 2018, from: <https://bit.ly/2Sa8Goc>.

GAlANTE, A.; MARTINI, F. Os 100 anos da Força de Submarinos e o PROSUB. Poder Naval, 2014. Retrieved Dec. 17, 2018, from: <https://bit.ly/32nGNh7>.

GFP - GLOBAL FIRE POWER. Total submarine strength by country. 2017. Retrieved Dec. 17, 2018, from: <https://goo.gl/HZQxvD>.

GROIZELEAU, V. Lorient: une école de conception pour les sous-marins brésiliens. Mer et Marine, 2010. Retrieved Dec. 17, 2018, from: <https://goo.gl/3Jm7WR>.

HARRIS, B. Submarine history: an illustrated survey of key events in the history of submarines. 2016. Retrieved Dec. 17, 2018, from: <https://bit.ly/2XGbtf1>.

HOFFMAN, G. 1954: lançado o primeiro submarino nuclear. Deutsche Welle (DW), 2018. Retrieved Dec. 17, 2018, from: <https://p.dw.com/p/1FVL>.

LANA, L. Submarinos: defesa e desenvolvimento para o Brasil. Rio de Janeiro: Versal, 2014. Retrieved Dec. 17, 2018, from: <https:/goo.gl/gttqKf>. 
MARQUES, A. L. F. A Marinha mostra o rumo. Carta Capital, v. 974, Oct. 18, 2017.

MOURA NETO, J. S. A construção do submarino de propulsão nuclear no Brasil. Techno News, ano 3, n. 13, 2012. Retrieved Dec. 17, 2018, from: <https://goo.gl/MB527b>.

NATION MASTER. Nuclear submarines: countries compared. 2014. Retrieved Dec. 17, 2018, from: <https://goo.gl/nLCeSK>.

NAVAL GROUP. Brazilians Submarines Programme: visit to the DCNS Cherbourg site by Jaques Wagner, Brazilian Minister of Defence. 2015. Retrieved Dec. 17, 2018, from: <https:// goo.gl/SUT4gA>.

NGB - NAVIOS DE GUERRA BRASILEIROS. Submarino F1: classe Foca. 2018. Retrieved Dec. 17, 2018, from: <https://bit.ly/2XHsyjD>.

NRP. Explained: how air independent propulsion (AIP) works! Defencyclopedia, 2016. Retrieved Dec. 17, 2018, from: <https:/goo.gl/yrpNbr>.

PADILHA, L. SBr - Submarino 'Riachuelo' (S40). Defesa Aérea \& Naval, 2012. Retrieved Dec. 17, 2018, from: <https://goo.gl/nkLzez>.

PAIVA, L. E. R. O jogo do poder na faixa atlântica do Entorno Estratégico nacional e seus reflexos para a defesa e projeção do Brasil. In: GHELLER, G. F.; GONZALES, S. L. M.; MELO, L. P. Amazônia e Atlântico Sul: desafios e perspectivas para a defesa no Brasil. Brasília: Ipea; NEP, 2015. p. 185-232.

PENNA FILHO, P. Reflexóes sobre o Brasil e os desafios do Atlântico Sul no início do século XXI. In: GHELLER, G. F.; GONZALES, S. L. M.; MELO, L. P. Amazônia e Atlântico Sul: desafios e perspectivas para a defesa no Brasil. Brasília: Ipea; NEP, 2015. p. 149-184.

PINTO, P. L. O emprego do poder naval em tempo de paz. Rio de Janeiro: Serviço de Documentação Geral da Marinha, 1989.

SCHMIDT, F. H. Desafios e oportunidades para uma indústria espacial emergente: o caso do Brasil. Brasília: Ipea, 2011. (Texto para Discussão, n. 1667). Retrieved Dec. 17, 2018, from: <https://goo.gl/pPmHX8>.

SHARDA. Different types of submarines and underwater vessels. Marine Insight, 2 de agosto de 2017. Retrieved Dec. 17, 2018, from: <https:/goo.gl/3o7eEP>.

SILVA, M. M. F. Submarino nuclear de ataque: nova dimensão estratégica para a defesa nacional. 2012. Monografia (Especialização) - Departamento de Estudos da Escola Superior de Guerra, Rio de Janeiro, 2012.

SILVEIRA, V. Governo inclui mais quatro projetos militares no PAC. Valor Econômico, May 3, 2013. Retrieved Dec. 17, 2018, from: <https:/goo.gl/9qoEZL>.

UNCITRAL - UNITED NATIONS COMMISSION ON INTERNATIONAL TRADE LAW. Legal guide on international countertrade transactions. New York: UNCITRAL, 1993. Retrieved Dec. 17, 2018, from: <https://goo.gl/eZ9BPe>. 
VIANNA FILHO, A. Estratégia naval brasileira: abordagens à história da evolução dos conceitos estratégicos navais brasileiros. Rio de Janeiro. BIBLIEX, 1995.

WILTGEN, G. 2016. Comando da força de submarinos completa 102 anos. Defesa Aérea \& Naval, Dec. 17, 2016. Retrieved Dec. 17, 2018, from: <https:/goo.gl/fexgGf>.

ZIMMERMAN, S. Submarine technology for the 21st century. Arlington: Pasha Publications, 1990. 

Ipea - Institute for Applied Economic Research

Press and Communications Office

\section{PUBLISHING DEPARTMENT}

\section{Coordination}

Reginaldo da Silva Domingos

Coordination Assistant

Rafael Augusto Ferreira Cardoso

\section{Supervision}

Camilla de Miranda Mariath Gomes

Everson da Silva Moura

\section{Typesetting}

Aeromilson Trajano de Mesquita

Cristiano Ferreira de Araújo

Danilo Leite de Macedo Tavares

Herllyson da Silva Souza

Jeovah Herculano Szervinsk Junior

Leonardo Hideki Higa

\section{Cover design}

Danielle de Oliveira Ayres

Flaviane Dias de Sant'ana

\section{Graphic design}

Renato Rodrigues Buenos

The manuscripts in languages other than Portuguese published herein have not been proofread.

\section{Ipea Bookstore}

SBS - Quadra 1 - Bloco J - Ed. BNDES, Térreo

70076-900 - Brasília - DF - Brazil

Tel.: + 55 (61) 20265336

Email: livraria@ipea.gov.br 

Composed in Adobe Garamond 11/13.2 (text)

Frutiger 47 (headings, graphs and tables)

Brasilia - DF - Brazil 

Ipea's mission

Enhance public policies that are essential to Brazilian development

by producing and disseminating knowledge and by advising

the state in its strategic decisions.

\section{ipea \\ Economic Research}

MINISTRY OF

ECONOMY
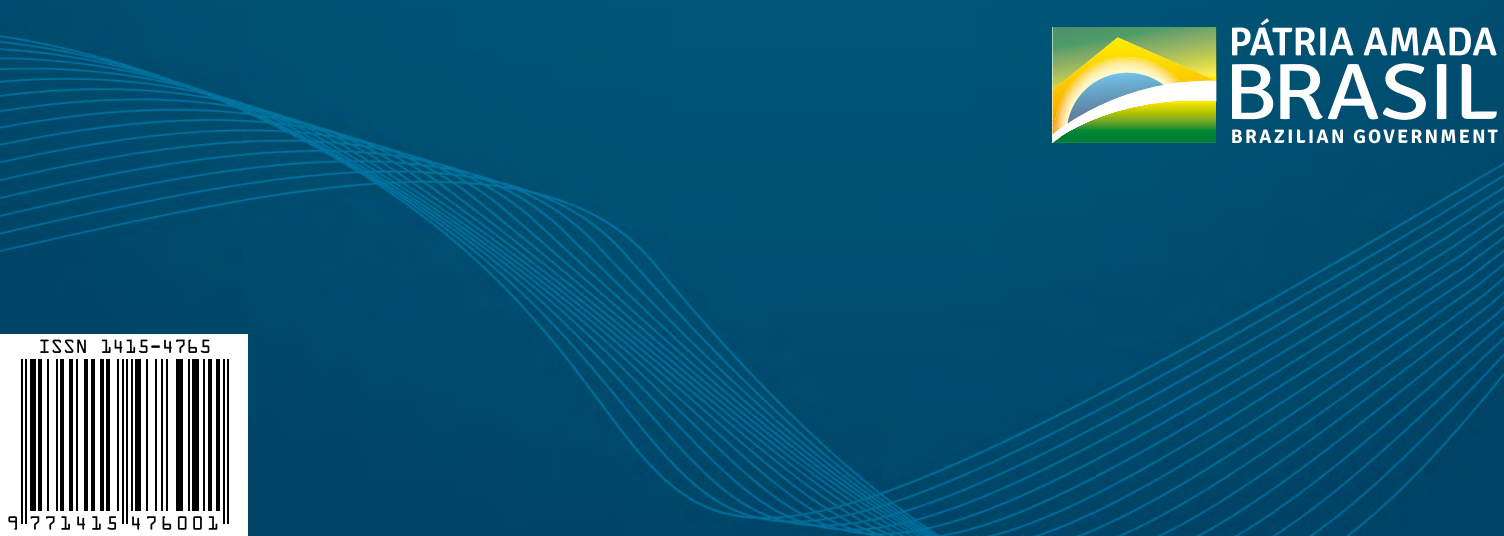